\title{
THE ADOPTION OF US-STYLE BUSINESS EDUCATION IN MEXICO, 1945-2005
}

\author{
LA ADOPCIÓN DE LA EDUCACIÓN \\ EN ADMINISTRACIÓN DE EMPRESAS ESTILO \\ ESTADUNIDENSE EN MÉXICO, 1945-2005
}

\author{
Bernardo Bátiz-Lazo* \\ Bangor University, Wales, United Kingdom, <b.batiz-lazo@bangor.ac.uk>
}

\begin{abstract}
This article maps the idiosyncratic features in the development of graduate and postgraduate management education in Mexico City. The emergence of these degrees is partly in response to the globalization of higher education but also to the transformation of Mexican business organisations into a more hierarchical structure. The evolution of the institutional setting thus offers an indirect study of the appearance of professional managers in a region otherwise dominated by family run firms. As a result, this article contributes to contemporary Mexican business history by linking the forms of interaction between multinationals, indigenous businesses and management education.
\end{abstract}

Key words: business elites, academic degrees, business schools, case method.

Resumen. En este artículo se identifican los rasgos clave del desarrollo de la educación universitaria para graduados y posgraduados en administración de empresas en la ciudad de México. Su creación responde tanto al proceso de globalización de la educación superior como también a la transformación de empresas mexicanas en organizaciones más jerarquizadas. Se ofrece un estudio indirecto del surgimiento de gestores profesionales en una región tradicionalmente dominada por empresas familiares. Así, este artículo contribuye a la historia contemporánea de la empresa mexicana al esbozar las formas de

* Acknowledgements: I am indebted to Robert R. Locke who contributed to an earlier draft, to Eve Richards and Sarah Wale for editorial assistance as well as to the comments of Peter von Standen, Alejandro López Arratia, John Wilson, Takeo Hoshino, Walter Friedman, Gustavo del Ángel, Rory Miller, anonymous reviewers and also staff presentations at Bristol Business School, London School of Economics, Management History Research Group, Oxford, and Centre for Research on Socio-Cultural Change (CRESC), Manchester, UK. The research benefited from the support of Jesús Quirce Andrés, L. C., Universidad Anáhuac; Javier Morales, S. J., Universidad Iberoamericana; Julián Sánchez García, Instituto Panamericano de Alta Dirección de Empresa; Arturo Fernández and Giovana Ximénez, Instituto Tecnológico Autónomo de México, and Cecilia Sandoval, Escuela Bancaria y Comercial. Research assistance was provided by Peng Wang, Bernardo Bátiz-Echavarria, Yolanda Lazo Margáin, the Francisco Xavier Clavigero Library at the Universidad Iberoamericana, and Antonio Bátiz Vazquez at Archivo Histórico BanameX. I am also indebted to all those who gave their time during interviews -most of whom remain anonymous- as well as data provided by the European Case Clearing House $<w w w . e c c h . c o m>$, and by the alumni offices of UK business schools. The usual caveats apply.

Am. Lat. Hist. Econ., año 20, núm. 1, enero-abril, 2013, pp. 158-198 
interacción entre multinacionales, empresas autóctonas y las instituciones de educación superior.

Palabras clave: elites empresariales, grados académicos, escuelas de negocio, método de caso.

Fecha de recepción: octubre de 2011. Fecha de aceptación: mayo de 2012

Para mí, la globalización de México significa la americanización.

For me, the globalization of Mexico means Americanisation. Jesús Silva Herzog ${ }^{1}$

\section{INTRODUCTION}

B $y$ the year 2000, the number of people that had gained or were seeking graduate and postgraduate education in business and management through local providers, travelling abroad or distance learning was overwhelming. These qualifications had their origins in USA and had become a global phenomenon. But why should US-style business education in Mexico be a topic worthy of attention?

During the second half of the twentieth century Mexico consolidated its status as one of the biggest trading partners of the USA as well as the second destination for tourists and US foreign direct investment. Trade integration gave Mexicans the chance to rank amongst the world's wealthiest individuals. ${ }^{2}$ But, in spite of this long interaction between local businesses and multinational enterprises, ${ }^{3}$ a dominant theme in Mexican business history ${ }^{4}$ has been a concern with the interaction between local elites and po-

${ }^{1}$ Contreras, Lejos, 2006, p. 20.

${ }^{2}$ In 2005, The Forbes Magazine ranked Carlos Slim Helú as the world's third richest person. “\#3 Carlos Slim Helu”, section Lists, The World's Billionaries, 2006, in <http://www.forbes.com/ lists/2006/10/WYDJ.html> [Accessed: October 31, 2008.]

${ }^{3}$ The first international joint venture in contemporary Mexican history dates from 1936 and it marks a return to the credibility of Mexican business ventures for US investors. This joint-venture was called Goodrich-Euzkadi S. A. between Ángel Urraza's Hulera Euzkadi, S. A. and US tire manufacturer B. F. Goodrich \& Co. However, it worth noting, first, that this joint venture grew from limits to foreign ownership by an increasingly nationalistic economic policy in Mexico. Second, Mexican companies had already begun to enter US markets on their own. For instance, Mexican breweries took advantage of anti-alcohol laws in the US, 1919-1933, to expand their country's domestic market, by exports to the US and other Latin American countries. By 1925 they represented $27 \%$ of the total federal income tax contributed by the manufacturing sector. See Recio, "Lawyers", 2004, pp. 290-291.

${ }^{4}$ The earliest systematic studies of groups, economic elites, or the so called gran burguesía in Mexico date from the 1960s namely, Kling, Mexican, 1961, and Vernon, Public, 1964. See also Baughman "Recent", 1965; Lauterbach, "Management", 1965, and Wionczek, "State", 1965. Con- 
litical power. ${ }^{5}$ For instance, there are valuable contributions looking at the impact of business people on the political system, ${ }^{6}$ the way in which they transformed their political representation ${ }^{7}$ and the changed relationship of the business community with the Mexican state at specific points in time. ${ }^{8}$

Along the lines of the interaction between local elites and the political system, Babb has documented the role of domestic and US-based elite education in the creation of technocrats in the public sector. ${ }^{9}$ Bátiz-Lazo and Haigh have documented the transfer of technical knowledge -partly created through job training- from public to private sectors. ${ }^{10}$ But little is known of the influence that elite education has had on the realm of private enterprise. Indeed, the emergence of master's degree in business administration (henceforth MBA) in Latin America and Africa is often portrayed as a recent development. ${ }^{11}$ In this regard, Hoshino has pointed to changes in Mexican business activities under economic globalization since the 1980s, but these form a trend which fails to consider management developments even though they introduced administrative innovations. ${ }^{12}$

Research in this article, therefore, documents the roots of the process by which higher education responded to changing needs in the Mexican labour market in the years following the end of the Second World War. This is a time when research and innovation were considered the keys to US economic and political supremacy and, by extension, as the Cold War progressed, the foundation upon which the contemporary capitalist world would be built. ${ }^{13}$ The discussion in the article highlights how ideas and techniques emerging in the large American firms migrated to large organisations elsewhere and how the managerial systems and educational forms which were suited to them migrated as well. Most -if not all- of these studies focus on developments, institutions and processes within Western Europe. But, with the exception of the work by Kipping and others, Lums-

tributions continued well into the 1970s as suggested by Arriola, "Grupos", 1976; Aubrey, "Capital", 1979; Rossi, Empresario, 1977; Shafer, Mexican, 1973, and Purcell and Kaufman, "Mexican", 1977.

${ }^{5}$ Aspe, "Caso", 2004; Camp, Entrepreneur, 1989; Garrido, "Liderazgo", 1998; Hernández, "Conducta", 1990; Luna, "Business", 2004; Maxfield, Governing, 1990; Maxfield and Anzaldúa, Government, 1987; Puga, Organizaciones, 1993; Salas, "Avenidas", 2002, and Zabludovsky, "Presencia", 1995. Also, Arzuaga, Racionalidad, 2004; Cerrutti and Marichal, Grandes, 2010; Ortiz, "Consejo", 2002, and Romero, "Panorama", 2003.

${ }^{6}$ Mizrahi, New, 1994, and Story, "Industrial", 1983.

${ }^{7}$ Hernández, Empresarios, 1991, and Schneider, "Why", 2002.

${ }^{8}$ Bensabet, "Strategic", 1999; Carrera, "Empresarios", 1992, and Valdés, "Bank", 1994.

${ }^{9}$ Babb, Managing, 2001.

${ }^{10}$ Bátiz-Lazo and Haigh, "Engineering”, 2012.

${ }^{11}$ Contreras, Lejos, 2006; Preston and Dillon, Despertar, 2004, and Starkey and Tiratsoo, Business, 2007, p. 10 .

${ }^{12}$ Hoshino, "Indigenous", 1990, and "Executive", 2005.

${ }^{13}$ McGlade, "Business", 1998. 
den, and Negrón ${ }^{14}$ we know little of the differences and similarities which led managers and educators in countries outside Europe, such as Mexico, to replicate practices and customs developed in the USA.

Documenting the history of the provision of graduate and postgraduate in business and management in Mexico City allows us, on the one hand, to set the emergence of the Anglo-American higher education model within a particular context, as well as the leadership role of individual providers and specific actors in initiating and maintaining responses. On the other, this results in an indirect map of the way in which the large indigenous firms and multinational organisations incorporated professional management as the Mexican economy grew in the post-war period..$^{15}$ The rationale for this process is as follows: for owners-senior managers of a rapidly expanding group of companies, a founder's family cannot simply fill all the management positions. The natural emergence of salaried administrators by specific, in-house training is time consuming. ${ }^{16}$ Local business organizations found that learning on the job had to be supplemented by formal training to ensure the acquisition of relevant knowledge and skills. At the same time, trade liberalization resulted in the growth of multinational companies, which increasingly used local talent as their sources for recruitment. Therefore, multinationals found themselves competing for the "best and the brightest" while having to offer pecuniary and nonpecuniary rewards which would off-set the opportunity cost of abandoning the family firm.

The creation and reproduction of salaried managers in Mexico has received some attention..$^{17}$ However, an area in need of greater study is the emergence and evolution of educational institutions which would produce salaried managers. Specifically, how did the institutional setting evolve to introduce graduate and postgraduate management education in Mexico? Was this an indigenous effort or was US-style management education imported from the outset? Answering these and related questions helps to ascertain the evolving nature of capitalism and the business enterprise in

${ }^{14}$ Kipping, Üsdiken and Puig, "Imitation", 2004; Lumsden, Americanization, 1970, and Negrón, Americanización, 1976.

${ }^{15}$ The recruitment, training and capabilities of the workforce as well as the evolving relationship between managers and workers in both production and in distribution are central to the history of the industrial enterprise. See Chandler, Scale, 1990, p. 13. However, a careful analysis of evolving labour relations is beyond the scope of my research project because analysing the transformation of labour relations is not the same as looking at changes and developments in the management of Mexican enterprise. But clearly the two are not to be disentangled from one another.

${ }^{16}$ Hoshino, "Family", 2004.

${ }^{17}$ Ibid., Lauterbach, "Management", 1965, and "Executive, 1964; Martínez and Ricks, "Multinational", 1989; Schuler et al., "Managing", 1996, and Slocum, "Comparative", 1971. 
Mexico. Indeed, to date there have been no systematic studies of Mexicans who studied management in the USA; American educators who went South to Americanise Mexican management education; and or the American management consultants who, by transferring US business practices and "know how", helped shape the modern Mexican enterprise. Yet their combined educational efforts are an essential part of the story about those who created the modern enterprise in this country as well as the Americanisation $^{18}$ of Mexican cadres from 1945 to 2005.

The research in this article aims to show how and why American style business practices emerged in a specific context and explores how higher education in Mexico coped with these changes. This perspective permits us to gain clarity about the process through which Mexicans have followed the lead set by developments in the United States. Moreover, the evidence in this article shows that Americanisation is not the sole remit of US-based education but also of European institutions and most notably those in the United Kingdom. Here there is an important caveat: namely, the discussion will focus on developments in Mexico City. This is important, because Mexico City makes significant contributions to the country's overall economy, it houses the largest labour market and there is close interaction between business and political elites. Although Monterrey and Guadalajara are also important business and educational centres, the historiography of Mexican business has often overlooked developments in the country's capital while giving prominence to organisations based in the North of the country.

The rest of this article proceeds as follows. The next section considers developments during the first era of globalization. The third section tells of the emergence of the provision of business and management courses in Mexican higher education, including the establishment of the first MBA programmes in private universities. The fourth section narrates how USstyle management education appeared in state universities. Developments that were partly a response to the innovation introduced by private universities. The fifth section deals with competition between the degrees (both part-time and full-time) offered by local and foreign providers. The sixth section presents a discussion of results, offers conclusions and points to

${ }^{18}$ Americanisation has been a significant subject in recent historical literature. History is the operative word here because Americanisation, as Locke and Schöne have pointed out, has not been conceived of as a "neutral analytical social science category", in Locke and Schöne, Entrepreneurial, 2004. Rather, it is a time-bound, value-loaded construct which emerged from historical actors who have uncritically benchmarked organisational processes, procedures and institutions in the US as best historical practice. Consequently, the content of Americanisation that occurred during the second part of the twentieth century varies according to the contexts in which has taken place. There has been, so to speak, not just a process of Americanisation but a series of Americanisations. 
potential avenues for further research. Finally, an appendix looks at trends in the topics of the international case studies set in Mexico and or focusing in Mexican companies.

But before proceeding a caveat. Mintzberg is among those who argue that there is a difference between educating managers (gestores), entrepreneurs (emprendedores) and business people (empresarios). ${ }^{19}$ In this division there is a debate on the overlap between formal training for the civil service and state owned firms (administración pública) and for private enterprise (empresa privada). As a result, the business school (escuela de negocios) is sometimes conceived as a different space from the school of management (administración de empresas). Although there are important conceptual differences between these categories and although a master's in management (maestría en administración) may offer distinct content and have different entry requirements from a MBA (maestría en alta dirección de empresas), the remainder of my article sidesteps the distinctions between them. This is in order to trace the overall development of vocational competencies amongst office workers, its transformation into a set of higher education degrees and the influence of US-style education in these efforts.

\section{TENTATIVE BEGININGS}

For some people management education in Mexico can be traced back to the creation of the Escuela Superior de Comercio in 1854. But these were technical-type certificates rather than university graduate diplomas. The history of the Escuela is in itself haphazard and fraught with discontinuities. The same can be said of the selected few who attended what was to become the National University (Universidad Nacional Autónoma de México, henceforth UNAM). Originally established in 1551 as the Real y Pontifícia Universidad de México, it also suffered severe disruptions. This reflected the volatility which permeated all aspects of Mexican life during the nineteenth century.

The National University remained the only higher education outlet in Mexico even after it was re-launched in 1910 by Justo Sierra, who gave it a mandate to "Mexicanize" knowledge. ${ }^{20}$ The creation of UNAM resulted in a number of schools and colleges coming together with a view to creating

${ }^{19}$ Mintzberg, Managers, 2004.

20 "UNAM at a glance. 1910, Origin and Organization of the National University of Mexico", section History, Brief History, en 100 Universidad Nacional de México 1910-2010, en <http:// www.100.unam.mx>. [Accessed: April 3, 2012.] Note that in 1929 the National University was granted autonomy from the Ministry of Education (Secretaría de Educación Pública). 
larger administrative units. The Escuela Superior amalgamated with the School of Law (Escuela Nacional de Derecho) and the School of Public Administration (Escuela de Administración Pública) to form the National School of Law and Social Sciences (Escuela Nacional de Derecho y Ciencias Sociales). In this process the Escuela Superior de Comercio was renamed the National School of Accounting and Management (Escuela Nacional de Contabilidad y Administración, here forth ENCA) ${ }^{21}$ Accounting and bank management courses retained their trade school character even after 1929 when the Escuela Superior de Comercio was put under the aegis of the National University.

Another development that took place in 1929 was the creation of the Banking School of the Banco de Mexico (Escuela Bancaria del Banco de México). This was an in-house school that offered specialist training in accounting and banking and which was founded alongside the establishment of a government-owned financial institution with central bank functions and a licence granting it a monopoly for issuing currency. ${ }^{22}$ However, in 1931 the Banking School closed as a result of a reorganisation leading the Banco de México to fully embrace its role as central bank. But it reopened in 1932 after Manuel Gómez Morín encouraged other members of the Banco de México's staff who had taught at the Banking School to pursue an independent charter leading to the creation of the first independent school in the broad areas of business and management, namely, the Escuela Bancaria y Comercial (henceforth EBC). ${ }^{23}$ The founding partners were Agustín Loera y Chávez and the eventual sole owner of the EBC, Alejandro Prieto Llorente.

In 1934, president Lázaro Cárdenas (1934-1940) and his minister of Education, Narciso Bassols, attempted to modify the Constitution and declared that all education in Mexico had to be socialist. A backlash from the incipient private sector followed. Elites managed to secure the continuing role of religious orders in primary education while high school was to remain largely in the hands of the state. Of particular importance were schools providing the last three years of high school provision (i. e. preparatoria), because they were feeder schools for the UNAM. Slowly but steadily, however, concessions were made for private providers to increase their offering. For instance, official recognition of the EBC's accounting degree took place in 1939, marking this accounting degree unique until 1947

${ }^{21}$ Anonymous, "Facultad", 1979.

${ }^{22}$ A single issuing bank with monetary control responsibilities was established following the Ley del Banco de Mexico of 1925. Until then, several banks had had a charter for issuing currency but only that of the Banco Nacional de México (BANAMEX) was accepted for payment in government offices. See Huerta, Agustín, 2005.

${ }^{23}$ Olvera, Diálogos, 2005, and Ortiz, "70 Aniversario”, 1999. 
when UNAM offered a similar qualification (i. e., one requiring at least nine years of full schooling before entry).

Meanwhile, the activity of multinationals was rather limited during the post-revolutionary period. FDI was less than $7 \%$ of gross domestic product (GDP) per annum between 1940 and $1968 .{ }^{24}$ This was to change after trade liberalization when US FDI stock tripled from 4381 million in 1983 to 11580 million dollars in $1991 .^{25}$

\section{GENESIS OF PRIVATE UNIVERSITIES}

The door for independent providers in higher education opened with the passing of the Reglamento para la Revalidación de Grados y Títulos Otorgados por Escuelas Libres Universitarias in $1940 .{ }^{26}$ This new piece of legislation had originally aimed to allow the establishment of an independent National Polytechnic (Instituto Politécnico Nacional, henceforth IPN, which was founded in 1936) to live alongside UNAM. But in effect it paved the way for the emergence of independent higher education institutions along the lines of the educational projects of Catholic orientation as well as the creation of "centres of excellence" backed by businessmen and, in other cases, Spanish intellectuals running from persecution at home.

Around this time there was a growth of private schools offering primary and secondary education while aiming to service migrant communities, sons of diplomats and expat managers from multinationals. The establishment of many of these was possible only after foreign-oriented independent schools complied with local requirements. Otherwise their degrees were deemed unsuitable (sin validez oficial) and graduates would be unable to progress to any recognized university in Mexico. For instance, this was a distinctive feature of the Mexico City College (sic, henceforth MCC) which was renamed Universidad de las Américas in 1963. ${ }^{27}$ Established in 1946 as higher education outlet of the American School (Colegio Americano), it aimed at preparing students for a US style education while by-passing official recognition of its studies by Mexican authorities. In 1951 it gained

${ }^{24}$ Ceceña, México, 1975, p. 142.

${ }^{25}$ Wilkie, Ochoa and Lorey, Statistical, 1993, p. 1062.

${ }^{26}$ See Álvarez, Educación, 1994, p. 2.

${ }^{27}$ Mexico City College changed its name to University of the Americas in 1963. Thanks to a grant from the Mary Street Jenkins Foundation and the US Agency for International Development, it moved to a purpose-built site in Puebla and changed its name to Universidad de las Américas, A. C. in 1970. In 1978 a Faculty of Business and Commerce was established (Escuela de Ciencias Económico-Administrativas) and that same year, a satellite campus in Mexico City opened. The formal separation from the American School Foundation came by mutual agreement in 1985 . 
acceptance by the Texas College Association as an abroad member and in 1959, MCC gained full membership of the Southern Association of Colleges and Schools. It is until 1968 when its degrees were officially recognized in Mexico. Moreover, it was the appointment of Fernando Macías Rendón in 1975 which marked a period of Mexicanisation, meaning the development and implementation of a marketing campaign to attract Mexican students en mass and from all corners of the country.

The popularity of business and management courses in private universities should also be seen in the context of economic growth and increasing urbanisation during the twentieth century. Regarding the latter, the first census in 1895 recorded 12300000 inhabitants, growing to 15200000 in 1910, the year which also marked the start of social unrest. The end of the worst armed fighting was that 14300000 inhabitants were recorded in 1921. Population then started to grow very fast. By 1950 it had reached 25800000 while 34900000 were recorded in the census of 1960. In other words, the population doubled in the thirty years to 1950 . But it was in the process of doubling again in the 20 years to 1970 (when the census recorded 48200000 ) and again in the next 25 years (reaching 91200000 inhabitants in 1995). At the same time, the number of people living in urban areas (with 2000 or more inhabitants) grew from 31.2\% in 1921 to $42.6 \%$ in 1950, to 58700000 in 1970 and $73.5 \%$ in 1995 . The growth of business and accounting by higher education outlets was thus intimately related to an increasingly urban population.

As for the economy -as measured by GDP-, it had grown at an apparently unstoppable rate. ${ }^{28}$ Starting in the early 1940 s, US markets opened to Mexican exports while unskilled labour was attracted to agriculture to support the war effort. Business opportunities were not only plentiful but some local and foreign business had managed to capture them. According to Ceceña, US foreign investment was present in all fifteen sectors of the 500 top Mexican businesses, ranging from a high $10 \%$ of total investment between 1947 and 1952; to a low 4\% between 1959 and $1965 .{ }^{29}$ At the same time, some indigenous organisations had grown substantially. For instance, at the Banco de Comercio (e. g. BANCOMER) and its affiliates, one of the largest banks in terms of assets, employees grew from 28 in 1932 to 11500 in 1965 and to 17284 in $1970 .{ }^{30}$ Cadres of middle managers were ever more evident as a growing urban population was finding employment in services (e. g. banks, insurance, engineering, utilities), manufacturing (e. g. car assembly plants, beer and soft drinks production and distribution,

\footnotetext{
${ }^{28}$ For a recent estimate see García-Verdú, "Demographics", 2007.

${ }^{29}$ Ceceña, México, 1975, p. 143.

${ }^{30}$ Cifras de "Bancos y Bancos Afiliados" in Ángel, BBVA, 2007.
} 
cement and steel) and the public sector (central and regional bureaucracy, as well as state owned firms).

Interestingly, when the opportunity came (or was sought) to enter higher education for schools associated with religious orders, they developed courses within the social sciences (e. g. economics, accounting, business, law) and this was timely because it addressed the growing needs of private and public enterprise. But it was also less capital intensive than developing provision in the natural sciences. Moreover, it benefited from the goodwill of a growing urban middle class: the latter was often already a customer of its educational offerings while, at the same time, parents without the benefit of owning their own business, any formal pension system or having been endowed with real estate, were concerned about future employment opportunities for their off-spring. Private education offered the possibility of differentiation in the job market.

Table 1 summarises the roots of independent universities at a time of incipient industrialization in Mexico, a period typically associated with the governments of Manuel Ávila Camacho (1940-1946) and Miguel Alemán Valdés (1946-1952). During the 1950s independent providers became an educational alternative to state universities. Because these were the early stages of industrialization there was limited demand for specialized training and education of the workforce. Nevertheless, independent higher education managed to attract (and have continued to attract) the off-spring of the Mexican bourgeoisie, not from Mexico City alone, but nationally. At the time, company management consisted of family, friends and a handful of devoted employees (those who had proven their loyalty after decades in the job). The career of Luis Reynoso at BANCOMER in this regard is telling. ${ }^{31}$ He joined the bank as an office boy in 1965 and almost immediately began work in the office of Manuel Espinosa Yglesias, the chairman. From there he transferred to a retail bank branch. He trained by learning on the job and grew to be branch manager. The same path took him to retire as one of the senior executives (director de Banca Patrimonial) in 2001.

Table 1 suggests that, as had been the case in Spain, ${ }^{32}$ independent higher education outlets were set up along the lines of local business and social networks. Links to Catholic orders are evident (e. g. Universidad Iberoamericana, here forth UIA; Universidad Anáhuac; Universidad Panamericana) as are the links between non-denominational, "centre of excellence" universities with certain business groups (e. g. Instituto Tecnológico Autónomo de México, here forth ITAM, Bailleres; Instituto Tecnológico y de Estudios Superiores de Monterrey, here forth ITESM, Garza Sada).

\footnotetext{
${ }^{31}$ Ibid.

${ }^{32}$ Puig and Fernández, "Education”, 2003.
} 


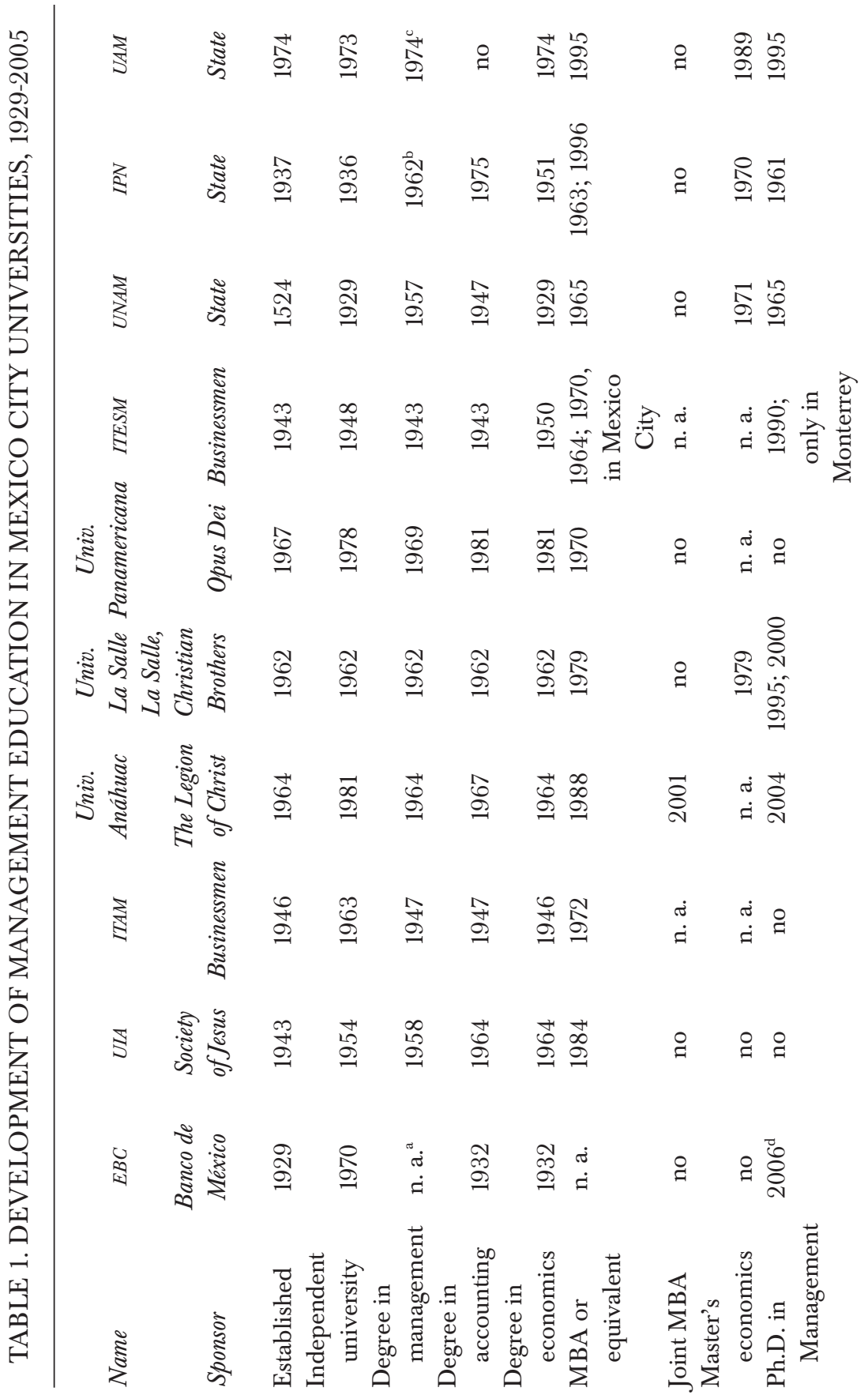




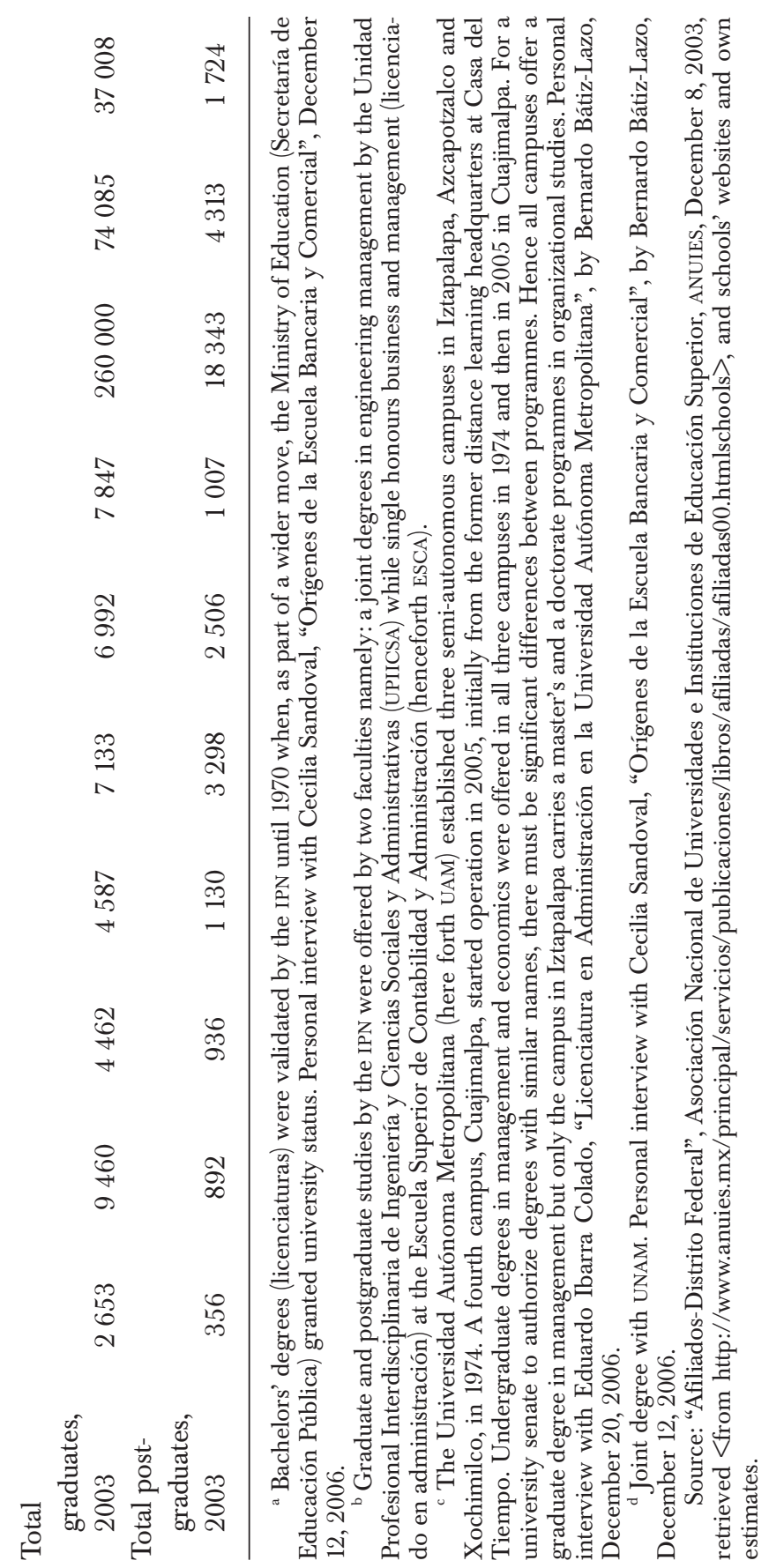


The orientation of these new outlets to specific social networks or grupos is important, since these are allegedly aware of innovations in foreign markets and educational systems, can easily recognize domestic business opportunities and have the necessary means and capacity to combine the latter and to create wealth. ${ }^{33}$ Moreover, the potential for wealth creation by the alumni of these new universities forms an important element in their conception. New graduates could exploit well established alumni for preferential access to employment opportunities, thus fostering the reproduction of those networks. Hence, the emergence of new independent higher education outlets suggests a shift in the education and formation of Mexican elites.

At the same time, an excess of dynastic successions had resulted in a low standard of managerial capability for most firms. Moreover, the concept of professional management was scarcely developed in most firms, mainly as a result of the absence of an organized hierarchy. As late as the mid-1970s, advisors to Mexican entrepreneurs and government officials were dismayed at the lack of professionalism:

A large portion of those who manage organisations in Mexico have had no management education and they come from other fields. As a result there is little appreciation of the complexity of management and of the knowledge to do it well. Intuition, common sense and even intelligence are seldom enough to manage well; ability is also required. The ability to manage does not come any more naturally than the ability to perform medical surgery. (This does not discard the value of "natural ability"; it states that it is seldom enough. $)^{34}$

Table 1 points to the ITESM as the first of the private higher education outlets to offer graduate and postgraduate education in the broad fields of business and management. ITESM was established in 1943 by a group of northern entrepreneurs under the leadership of the local magnate Eugenio Garza Sada, who had graduated from the Massachusetts Institute of Technology. Although the undergraduate degree in business administration was not part of the original provision, early activities included an executive education and post-experience training centre (called Centro de Investigación y Capacitación Empresarial). The first undergraduate degree in business administration (licenciado en administración) was established

${ }^{33}$ Cerón, "Identity", 2003, and Madrid, Cambio, 2004.

${ }^{34}$ Ackoff, "Some", 1976, p. 86. It is worth noting that Ackoff had been providing training executives in Mexico, Mexican doctoral students in the US and management consulting to private Mexican firms since the mid-1950s. Personal correspondence Ackoff with Bernardo Bátiz-Echavarria, December 20, 2005. 
in $1948 .^{35}$ This was followed by the master's and doctoral programmes in management in Monterrey and from 1970 onwards, a part-time master's degree in management on location for executives in Mexico City. However, by 1978 the part-time programme in Mexico City was attracting only some 25 students per annum and was thus abandoned.

The creation of a school of business and management at ITESM between 1950 and 1970 came from their leanings towards a US-style education. First, ITESM acquired in 1950 recognition of its studies from the USbased Southern Association of Colleges and Schools. Second, it developed relevant expertise. This was acquired by hiring full-time US professors in management and it also developed organically by sponsoring and attracting Mexicans trained on master's and doctorate programmes in the USA. During the 1970s, ITESM grew to be the biggest private provider of traditional and distance learning in Mexican higher education. This was followed by a reorganisation into a multi-campus university in 1986. Its fully fledged business school (Escuela de Graduados en Administración de Empresas, henceforth EGADE) was established in Monterrey as part of another internal reorganisation in 1995. In 1998 and thanks to 21000000 dollars' worth of donations from friends and alumni, EGADE relocated from the main campus in downtown Monterrey to a purpose built development on the outskirts. By now the ITESM system had built three campuses in Mexico City (Lago de Guadalupe, 1973; Tlalpan, 1994; and Santa Fe, 2001) which in 2006 together captured about half the provision of first degrees in business and management by the top ten private schools in Mexico City. ${ }^{36}$ By then a fully US-accredited, part-time MBA was also on offer in Mexico City, while doctoral studies were limited to the main campus at EGADE in Monterrey.

But while ITESM went from strength to strength in undergraduate teaching, success in full-time MBA programmes was to take place elsewhere. The roots of this success date from 1949 when Pedro Casciaro arrived in Mexico to indoctrinate locals into the Opus Dei. ${ }^{37}$ In 1965, its founder, Josemaría Escrivá de Balaguer, asked his representatives in Mexico to explore the possibility of starting a university. At the same time and in an apparently independent move, Manuel Senderos, general manager of a large insurance company (director general de Seguros la Comercial), expressed

\footnotetext{
${ }^{35}$ Personal interview Germán Otalora Bay, "El Tec en la ciudad de México", by Bernardo Bátiz-Lazo, December 22, 2006.

${ }^{36}$ Personal interview Carlos Alcerreca, "Escuelas de negocios en la ciudad de México", by Bernardo Bátiz-Lazo, December 20, 2006.

${ }^{37}$ Unless otherwise stated, the remainder of this section borrows freely from my interview with Carlos Rossell, "El origen del MBA en el IPADE", by Bernardo Bátiz-Lazo, September 2, 2008, and Rossell, Vivencias, 2007.
} 
to his spiritual director and Opus Dei prelate, Ramón Labiaga, his interest in training top managers along the lines of US-style business schools but with a Christian orientation. Labiaga introduced Senderos to another top businessman who shared his views and was also a member of Opus Dei, namely, Gastón Azcárraga Tamayo, then head of the Mexican joint venture with Chrysler (director general de Fábricas Automex).

Casciaro pursued each of those projects as distinct efforts, one relating to the university and another which would inspire in the business school a similar institute to the one which Opus Dei had started in Spain in 1958 (Instituto de Estudios Superiores de la Empresa, henceforth IESE). The Mexican government initially refused to provide official recognition to a university. However, Casciaro, under instructions from Escrivá, persisted and was instrumental in the establishment of the Instituto Panamericano de Humanidades (here forth IPH). It offered its first undergraduate programme in 1969 and was then granted university status in 1978, changing its name to Universidad Panamericana.

The training of top managers was to remain operationally and physically independent of IPH. So, while IPH was establishing itself in the south of Mexico City, a former farm (hacienda de Clavería) ${ }^{38}$ in the north east of the city was offered to Opus Dei by its then owners, the Manterola family. This was to house the business school after Senderos purchased, renovated and donated it for this purpose.

As had been the case at IESE (which took its inspiration and support from the Harvard Business School), ${ }^{39}$ what was to become the Instituto Panamericano de Alta Dirección de Empresas (henceforth IPADE) was initially developed in 1967 as an advanced management programme for owners and managers of small and medium-sized businesses. ${ }^{40}$ Most teachers were recruited locally, but with instructions from Escrivá to attract others from all over the Americas. Some had doctorates (e. g. Sociology) and some had industrial experience, such as Carlos Llano Cifuentes who ran his family business. They were to be trained in management specialisms in Spain at IESE, and later on, in several US outlets, including Harvard.

The initial success and continued backing of top businessmen such as Senderos and Azcárraga, Antonio Ruiz Galindo and Vicente Ariztegui in Mexico City and Carlos Gutiérrez Nieto in Guadalajara; led to the launch-

\footnotetext{
${ }^{38}$ The hacienda was a large, autonomous, self-sustaining holding of private land typically associated with agriculture or mining. During the colonial period, it grew to be the dominant productive unit and remained so until the 1930s.

${ }^{39}$ Kipping, Üsdiken and Puig, "Imitation", 2004, p. 102, and Puig and Fernández, "Education”, 2003.

${ }_{40}$ In 1980, IPADE amalgamated to become the graduate school of business and management for the Universidad Panamericana while maintaining its operational and physical autonomy.
} 
ing of its flagship programme in 1970: a US-style, two-year, full time MBA, specifically aimed at developing cadres of future top executives.

\section{RESPONSE FROM STATE UNIVERSITIES}

The response of state higher education to the growing popularity of business courses in private outlets came in the form of a more diversified offering. The pioneer in postgraduate education was the IPN. It was responsible for the first postgraduate course in management in Mexico (and indeed, Latin American) following the creation of a graduate school within ESCA, called Centro de Investigación y Estudios Avanzados. ${ }^{41}$ Planning for masters' and doctoral programmes in management started in 1959 through an ad hoc committee composed of academics and an advisory board of practitioners from the public and private sectors. ${ }^{42}$ The programme aimed to deliver graduates that could do well in either public sector or private enterprise. The motivation for launching postgraduate courses and the early experience of setting them up and attracting students were attended with some secrecy, perhaps because IPN aimed to recruit primarily from its own alumni rather than the public as a whole. By 1963 half the graduates of the first master's cohort had stayed on to the doctoral programme. ${ }^{43}$ Interestingly, postgraduate courses were the priority. ESCA's own graduate course in management was offered until 1975. In the meantime, the master's programme remained viable while the doctoral programme increasingly attracted research in the public sector and was eventually re-launched in 1996 to encourage research into private enterprise.

Meanwhile, in 1957, UNAM became the first Mexico City-based state university to offer undergraduate education in business and management when the $\mathrm{ENCA}^{44}$ introduced a undergraduate degree in manage-

\footnotetext{
${ }^{41}$ A similar outlet was created by UNAM's ENCA and called Instituto de Investigaciones Contables y Administrativas. The exact date when it was established is unclear but it took place during the tenure of Wilfredo Castillo Miranda as head, 1949-1957, of ENCA. The purpose of the Institute seems primarily to have been to help graduates with their final year's dissertation. There was no reference in archival records nor during interviews that this research institute played any role in the creation of the graduate programmes in management at UNAM. See Pallares, "Nuevo", 1957, p. 95 .

${ }^{42}$ Rodríguez, Escuela, 1995.

${ }^{43}$ Ibid.

${ }^{44}$ Similar acronyms and the sharing of dwellings eventually led to confusion as to whether IPN or UNAM was the "true" descendent of the Escuela Nacional de Comercio. This confusion dates to 1936, when the newly created IPN absorbed the building which housed the ENCA as part of the School of Economic, Administrative and Social Sciences (Escuela Superior de Ciencias Económicas, Administrativas y Sociales, henceforth ESCEA). Many of ENCA's staff were to remain at UNAM but were housed in an alternative location also in downtown Mexico City. In 1951 the
} 
ment (licenciado en administración). The idea of a degree in management emerged when the advisory board of the ENCA ( $\mathrm{H}$. Consejo Técnico ${ }^{45}$ ) acknowledged that a growing number of accountants had found employment in large organisations but their day-to-day activities were increasingly outside their functional area. ${ }^{46}$ The response was to offer a dual undergraduate degree to accounting alumni and current undergraduates if they extended their four year programme for a further two years of study. At the time, there were some 3000 students in the school and over 4500 accounting alumni -of whom only 500 had a full graduate degree or one awarded after submitting a dissertation and sitting a final oral and written examination. ${ }^{47}$

Undergraduates in the Law School were also invited to join the business administration programme, for two reasons. First, there was a wide overlap in provision as the accounting undergraduates shared six courses from the law programme. ${ }^{48}$ Second, by the late 1950s Law School education was the field with highest prestige in Latin America, exceeding all other categories of university education, while in Mexico, UNAM was preeminent for the number of its graduates. ${ }^{49}$ Indeed, at the time, a significant number of leading entrepreneurs held law degrees. ${ }^{50}$

Some graduates and undergraduates did register but many claimed that the two-year top-up required as much effort as a master's programme. The UNAM responded by keeping the degree in management as a standalone programme. The decision found little resistance because the management programme was attracting full-time students in its own right. The decision also involved introducing a master's in management (maestría en

ESCEA is partitioned, as IPN expands its offering of courses in economics. The latter is housed in the School of Economics (Escuela Superior de Economía) while accounting and business and management courses remain at ESCEA. In yet another twist, ESCEA adopts the older and more prestigious name of Escuela Superior de Contabilidad y Administración in 1952, a name which it has kept to this day. Personal interview with María de los Ángeles Rodríguez, "Antecedentes de la ESCA", by Bernardo Bátiz-Lazo, February 18, 2005, and Rodríguez, Escuela, 1995.

${ }^{45}$ The advisory board of the ENCA (referred to as either H. Consejo Técnico del Plantel or Consejo Técnico de la Escuela) was formed from 24 academic staff and four student representatives. The academic staff included 17 accountants, three lawyers and four others. Pallares, "Cómo", 1956, p. 7.

${ }^{46}$ Personal interview with Daniel Galindo, "De la maestría en administración al MBA", by Bernardo Bátiz-Lazo, December 18, 2006, and Roberto Hayaux du Tilly Palmer, "El MBA en la UNAM", by Bernardo Bátiz-Lazo, December 19, 2005.

${ }^{47}$ Pallares, "Cómo", 1956, and "Nuevo", 1957.

${ }^{48}$ These were Introduction to Law (Nociones e Introducción a la ciencia de Derecho), Commercial Law (Derecho Mercantil), Constitutional Law (Derecho Constitucional), Business Law (Derecho Administrativo), and Fiscal Law I and II (Derecho Fiscal 1 y 2). Pallares, "Cómo", 1956, p. 10.

${ }^{49}$ Tucker, “Mexican”, 1969, p. 805.

${ }^{50}$ Recio, "Lawyers", 2004. 
Administración) in 1965 as well as a doctorate in business administration in 1967. With this move, ENCA grew in status and converted into the Faculty of Commerce and Administration (Facultad de Comercio y Administración, henceforth FCA).

It is worth emphasizing that in the 1960s Mexico remained a widely illiterate country. ${ }^{51}$ Many entrepreneurs were "self-made men" while most staff had been trained and educated on the job. However, in a survey of Who's who in Latin America by Tucker ${ }^{52}$ the number of university diplomas in Mexican biographies was $85 \%$ in $1935,86 \%$ in 1940 , and $97 \%$ in $1946 .^{53}$ Although full figures were not on hand for 1951-1961, "available data and personal observation" indicated similar high levels of education. Moreover, "the proportion of biographies with some degree of education abroad [was] rising, with Europe favored [sic] in the earlier years and the U.S. more recently" ${ }^{54}$ The high proportion of university diplomas amongst the entrepreneurial elite was thus remarkable when compared to the high levels of illiteracy and low educational achievement elsewhere in society.

As opposed to the "organic" experience at IPN, the introduction of the master's degree in management at UNAM benefited from external support. On the back of the so called Sputnik effect and the Alliance for Progress, the Ford Foundation was among those private and public organisations that developed a commitment to exporting US management techniques and ideas. ${ }^{55}$ The Ford Foundation offered scholarships to recent Mexican graduates looking to become part of the staff of the FCA so that they could pursue a master's in business administration or MBA in the USA -opportunities which, at the time, not many were interested in seizing. ${ }^{56}$ One of the requirements of these scholarships was for MBA graduates to return to

${ }^{51}$ In the year 2000 the rate of illiteracy in Mexico was the lowest for the population of 15 to 19 years of age, 3\%, while it was highest for those between 60 to 64 years of age, $24.9 \%$. Illiteracy was more acute in rural areas, $17.8 \%$, and lowest in urban areas, 3.5\%. Not surprisingly, it was above the national average in the states with the lowest per capita income-Chiapas, 21.5\%; Oaxaca, 18.1\%, and Guerrero, 17.6\%-, but not in the highly industrialized states -Distrito Federal, 2.1\%; and Nuevo León, 2.4\%. Instituto, Anuario, 2004.

${ }^{52}$ See Tucker, "Mexican”, 1969.

53 Ibid., p. 804.

54 Ibid.

${ }^{55}$ The orbiting of the artificial satellite Sputnik I (PS-1) on October 4, 1957 by the USSR shook the confidence of the US in their capacity to lead the world in science, technology and general knowledge. Public and private sources pumped billions into university-based research. As an economic policy for the containment of Soviet expansion this took the form of generous flows of funds to the market economies of Western Europe, Latin America and the Far East. For a summary and its impact in revitalizing the MBA and US graduate education in business abroad, see Mintzberg, Managers, 2004, pp. 20-30.

${ }^{56}$ Personal interview with Roberto Hayaux du Tilly Palmer, "El MBA en la UNAM", December 19, 2005, and with Francisco Mendoza Trejo, "El MBA en el ITAM", both by Bernardo Bátiz-Lazo, December 21, 2005. 
academia and become instrumental in the development of postgraduate courses. Notable examples included Roberto Hayaux du Tilly at UNAM and Francisco Mendoza Trejo, who shortly after returning to UNAM moved to a private university, the ITAM in 1972. Mendoza Trejo headed the master's in management and related programmes until he resigned from ITAM in 1990.

But in spite of their early start state institutions were very quickly marginalised from graduate and postgraduate education in business and management for the elites. On the one hand, the IPN had a vocation to attract working and lower middle class students and provide them with employable skills. As mentioned above, it focused on researching public sector management. On the other, during the 1950s and 1960s left-wing ideas spread within UNAM from those teaching philosophy, history and the arts to economics and other social science faculties. The teaching of these ideas found little sympathy amongst the top echelons of Mexican enterprise ${ }^{57}$ During the following decades, UNAM maintained some stature in the "hard sciences", thanks to its large laboratories, links with hospitals and other facilities. But despite a large active research staff, in the aftermath of the first student revolt in 1968, the demise of UNAM as a focus of elite education in the social sciences accelerated as the Echeverría (1970-1976) administration and his successors implemented a policy of massive intakes of students at state universities -with UNAM reaching 260000 registered students in $2003 .^{58}$

\section{FULL-TIME OR PART-TIME?}

In 2006, IPADE was the only outlet in Mexico that had successfully developed a full-time MBA. Since the early 1970s it had recruited in double digits and by 1990 the average intake was 100 people, of whom some 90 graduated; that is, in the late 1980s and early 1990s as many as 200 students in campus per annum were common. ${ }^{59}$

Success at IPADE was partially explained by the support of a close-knit group of industrial leaders. But this success was in sharp contrast to most other attempts to develop full-time programmes. These were offered as both master's degrees in management and MBAs; that is to say, the original title in Spanish (maestría en administración) was increasingly being

${ }^{57}$ Personal interview with Carlos Rossell, "El origen del MBA en el IPADE", by Bernardo BátizLazo, September 2, 2008.

${ }_{58}$ Meneses, Universidad, 1979.

${ }^{59}$ Personal interview with Carlos Rossell, "El origen del MBA en el IPADE", by Bernardo BátizLazo, September 2, 2008. 
replaced by the US acronym (MBA), not only in content but also in name. But in spite of the changes in branding and perhaps pedagogy, every other attempt than that of IPADE found it hard to recruit even 20 students per annum. All other providers, both state-run and independent, found it economically viable to offer only part-time programmes. They also failed to recruit from the top, "heirs apparent" or "up and coming stars", while having a strong bias in favour of middle and line managers (including engineers from the growing manufacturing sector).

The explanations offered for this apparent failure included a dearth of active research staff..$^{60}$ One other reason was that in some schools almost $95 \%$ of the provision had traditionally been delivered by part-timers, resulting in little continuity and variable quality in what was on offer. ${ }^{61}$ But the chief reason was that most of the students willing and able to overcome the opportunity cost of full-time education overwhelmingly chose to pursue graduate studies in the USA and, to a lesser extent, Europe, mainly the UK.

An indication of the trends in the full-time versus part-time decision can be found in scholarship programmes. One of these started in 1953 when the Banco Nacional de México (BANAMEX), the biggest in terms of total assets and with 41845 employees in 1954, set aside dedicated resources for its employees to pursue external programmes -to complement the bank's in-house teaching efforts. ${ }^{62}$ Initially employees benefited from language courses in English and French, undergraduate courses at the Escuela Bancaria y Comercial while two grants were made available for courses in the USA ${ }^{63}$ The programme grew in popularity and some two to five employees were financed each year to pursue professional development and "hands on training" in banks based in the USA. ${ }^{64}$ The nature of the programme reflected the "life-long" employment which dominated banking at the time and thus the fact that the bank recruited relatively few university graduates. This was to change in the 1970s.

${ }^{60}$ Montaño, "Investigación”, 1999, and Pariente, “Formación”, 2006.

${ }^{61}$ Ma. Elena Escalera, "Posgrados en administración en la Universidad La Salle", by Bernardo Bátiz-Lazo, December 13, 2005.

${ }_{62}$ According to Silva, there was a precedent to the 1953 programme when in 1930 BANAMEX attracted some fifteen "highly qualified individuals" to implement a more "scientific organization of management". These came in as trainees, worked in several parts of the bank and some even received scholarships to study in Europe. However, less than a handful of them remained for long and some even left to take part in establishing what would become BANAMEX's main competitor, Banco de Comercio (BAnComer). See Silva, "Banco", 1999, p. 116.

${ }^{63}$ Personal interview with José Antonio Bátiz Vázquez, "Algunos datos sobre el 'personal' en los años de 1944 a 1964", by Bernardo Bátiz-Lazo, November 23, 2004.

${ }^{64}$ Personal interview with José Antonio Bátiz Vázquez, José Miguel Aguillón Banda and Salustio Ramírez, "Antecedentes y orígenes del programa de becarios BANAMEX”, by Bernardo Bátiz-Lazo, December 13, 2006. 
In 1971 there was a large enough number of graduates, in particular graduates in economics, working in the Economic Studies Department of Banamex (Departamento de Estudios Económicos). ${ }^{65}$ Senior management then decided to support postgraduate students abroad. ${ }^{66}$ Initially they pursued programmes in economics, first, Manuel Zepeda Payeras, who attended the University of Chicago and shortly afterwards Santiago Levy Algazi, at Boston University. ${ }^{67}$ Some 20 students followed in the next ten to fifteen years. The relatively low number reflected the highly volatile exchange rate between 1976 and 1985, which severely curtailed both individual and institutional efforts to study abroad. ${ }^{68}$

The number of employees receiving support on graduate courses abroad was to increase once macro-economic conditions grew more stable. A total of 192 people was sent by BANAMEX between 1989 and 2001, ${ }^{69}$ in other words, an average of fifteen employees per annum (with a minimum of five per annum in 1989, 1990 and 1991 and a maximum of 25 in 1993). Of these, 159 pursued a graduate course in North America, with the USA hosting $81 \%$ of the total and Canada, $2 \%$. They studied at top institutions such as the Massachusetts Institute of Technology, 7\%, and Harvard, $5 \%$, and also at others including Iowa, Texas at Austin and Thunderbird in Arizona. A minority pursued graduate studies in Europe, namely, in the UK, 8\%, Spain, 7\%, and other countries such as France, the Netherlands and Italy, together accounting for 3\%. Interestingly, $64 \%$ of the total of foreign graduate studies sponsored by BANAMEX pursued an MBA while the remainder, $36 \%$, sought courses which would be relevant for a banking career, notably specialist programmes in finance, economics, international business, information technology and applied statistics (see table 2).

Table 2 shows a similar pattern amongst graduates of Mexican origin in England to that observed by BANAMEX's staff abroad. Looking at programmes in England is important, for several reasons. First, BANAMEX staff consistently targeted postgraduate courses in economics at the University of Reading and the London School of Economics. Second, since the establishment of the first business schools in London and Manchester in 1968 the UK had been rather successful in attracting foreign students to its USstyle MBA programmes. Third, programmes in England have been a source

${ }^{65} \mathrm{Ibid}$.

${ }^{66}$ Aveleyra, Notas, 1988, p. 28.

${ }^{67} \mathrm{Ibid}$.

${ }^{68}$ Personal interview with José Antonio Bátiz Vázquez, José Miguel Aguillón Banda and Salustio Ramírez, "Antecedentes y orígenes del programa de becarios BANAMEX", by Bernardo Bátiz-Lazo, December 13, 2006.

${ }^{69}$ Estimates in the remainder of this paragraph were sourced in data provided by Juan Pablo Ortiz Tirado Kelly, "Programa de financiamiento a posgrados, 1989-2001", BANAMEX, by Bernardo Bátiz-Lazo, December 25, 2004. 
of "interesting innovations", moving away from the functional approach in the USA and Canada. ${ }^{70}$ Fourth, the UK has traditionally been the second biggest source of FDI into Mexico (averaging 4.4\% of accumulated FDI between 1994 and 2004, compared to the 60\% averaged by US investments for the same period). Fifth, a practical consideration, repeated requests to US schools for similar data were ignored. Not one of the destinations for BANAMEX nor in the alumni databases of top Mexican universities (ITAM, Anáhuac, UIA) cared even to acknowledge my many requests for a response, whereas British schools were ready with information to support the present research.

The distribution is skewed, first, because of the greater worldwide popularity of the MBA as a degree. Growth in popularity of the MBA for Mexicans, therefore, reflects the active part taken by Mexican graduates in a greater process of globalization. Second, the trend of Mexicans pursuing an MBA in Britain seems to have a high linear correlation with greater macroeconomic stability at home. Table 2 includes four measures of macroeconomic stability, namely, a nominal exchange rate with the US dollar (FX), real GDP at 1970 prices, accumulated FDI, and the consumer price index -for which 1985 equals one. All the four measures of macroeconomic stability in table 2 show greater volatility between 1968 and 1991 than between 1992 and 2004 .

A third element relates to the transformation of Mexican businesses. Economic reforms introduced between 1982 and 1992 saw the removal of barriers to international trade, a substantial reduction in the size of the state through privatisation, changes in fiscal policy and many other areas, in particular the signing of the North American Free Trade Agreement (NAFTA) in 1992. This was a process of transformation for Mexican enterprises, since only 17 of the top 100 companies in 1976 remained at the apex until 2005, as ranked by Expansión. ${ }^{71}$

By 2005, the MBA had had an impact on Mexican entrepreneurial elites. In the 500 top companies, as ranked by Expansión, 52 of the chief

${ }^{70}$ Mintzberg, Managers, 2004, and Starkey and Tiratsoo, Business, 2007.

${ }^{71}$ This estimate should be viewed with care because the rankings by Expansion are highly volatile. In particular for any comparison including 1976, which was the index's first year, when it lacked any repute. A simple comparison of the 1976 and 2005 rankings would suggest that two leading companies were State-owned -Comisión Federal de Electricidad and Petróleos Mexicanos-, three had been privatized -Teléfonos de México, Aereonaves de México and Altos Hornos de México-, four were subsidiaries of foreign companies -Grupo Cifra (Wal-Mart de México), Kimberly Clark de México, General Motors de México, Chrysler de México- and eight were indigenous firms -Nacional de Drogas, Industrias Unidas, Industrias Peñoles, Industrial Minera México, Fomento de Industria y Comercio (Fomento Económico Mexicano, FEMSA), El Puerto de Liverpool, Condumex, Compañía Mexicana de Aviación. For a systematic analysis of the survival and persistence of large Mexican companies between 1970 and 2005, see Cerda, Leading, 2007. 


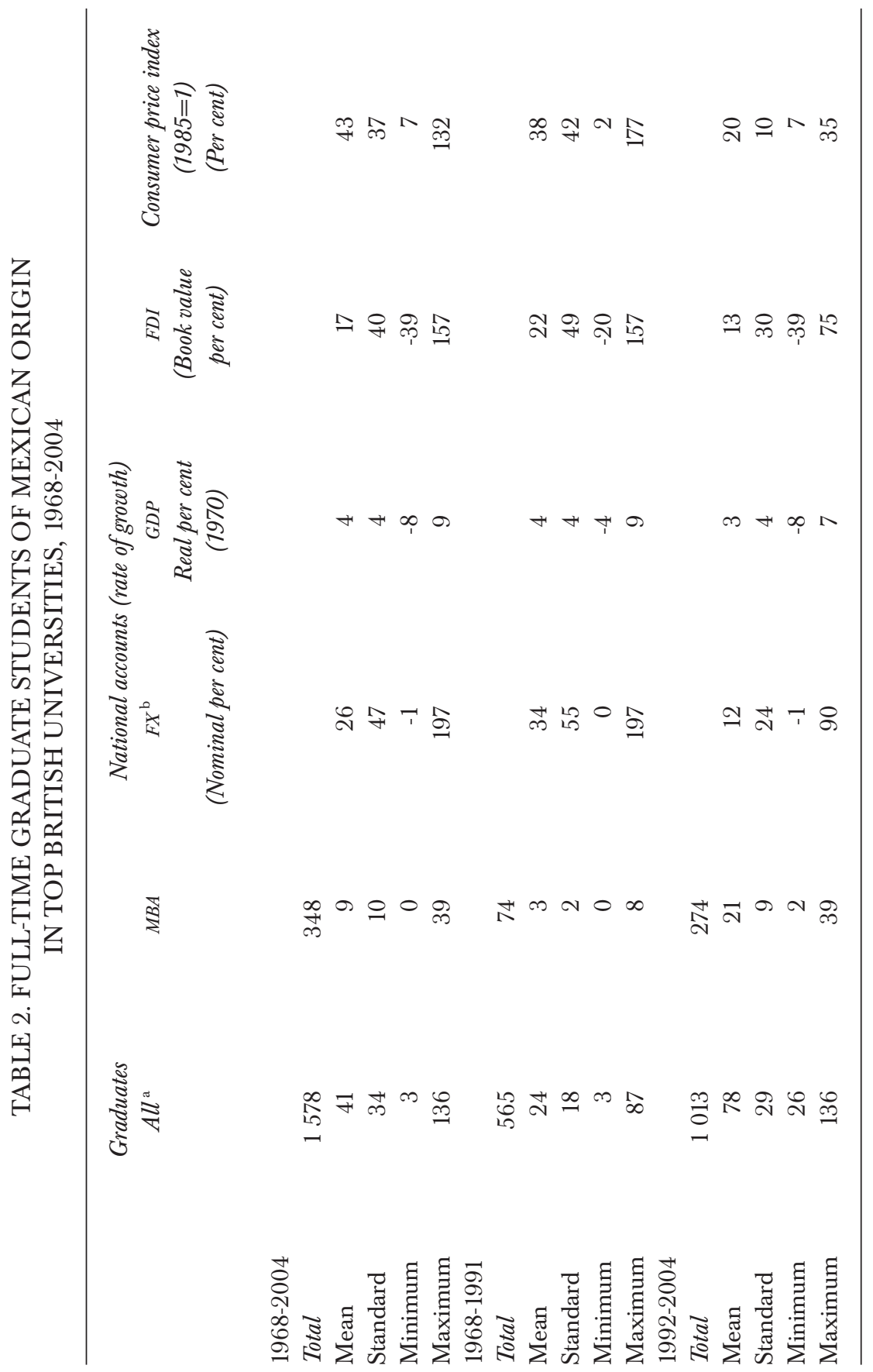




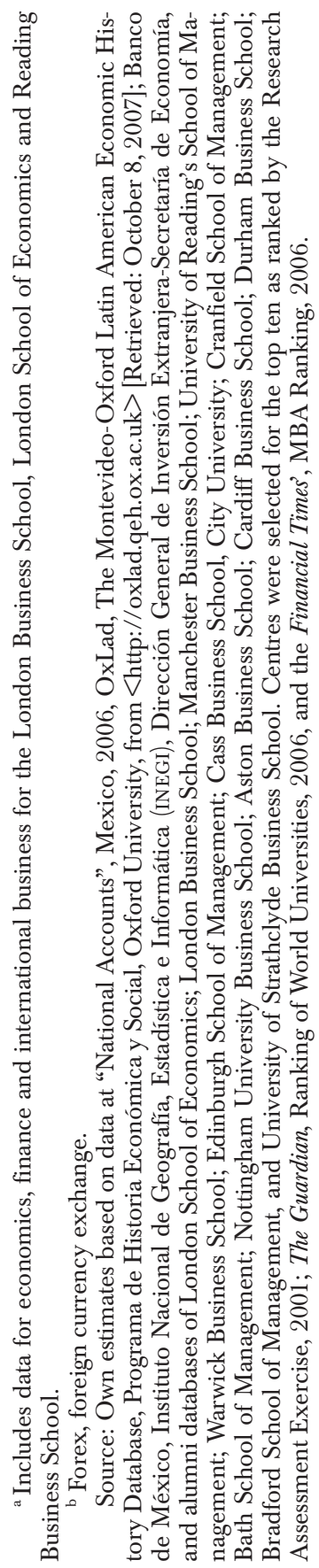


operating officers (henceforth CEOs) (director general, director consejero or presidente) had graduated from the ITAM. ${ }^{72}$ Of these 29 , or $56 \%$, had received only a first degree: eleven in economics, ten in accounting, five in management, two in law and one in actuarial studies; 19, 37\%, had a postgraduate degree from ITAM: 18 an MBA and one a master's in economics; while four had other diplomas. ${ }^{73}$ All of ITAM's CEOs were male. This is not surprising, since only five of the 500 CEOs were female and between 1968 and 2004 only 18 females $-21 \%$-, altogether graduated from Manchester Business School and the London Business School (69 males). ${ }^{74}$ In short, in spite of large numbers of female graduates in business and management, the MBA -whether full-time or part-time- and, to a greater extent, the corporate office were still a male preserve in Mexico.

\section{CONCLUSIONS}

The main focus of this article is the emergence and development of graduate and postgraduate management education in Mexico City since 1945. This story tells how educational efforts are an essential part of the history of Mexican cadres and the transformation of Mexican enterprise at the end of the twentieth century. As they did in the late nineteenth century, elites still back up educational projects linked to religious orders of the Catholic Church to develop an alternative system to that offered by the state. This system facilitates the creation and reproduction of social networks. However, nothing is said here about the objectives of the religious orders, their overlap or otherwise with the business elites or indeed the extent to which a Christian orientation to the educational project deals with rather a nationalistic and non-denominational orientation of state education authority. Neither was there a discussion as to whether the content of the programmes indeed followed Christian principles or simply adopted US syllabuses, content and textbooks. Little was said of executive training, management consultants or US academics in Mexico. Perhaps these are areas for future research, as is the transformation of the educational profile

72 The MBA programme at ITAM was ranked fifth, fourth and second in importance in Latin America by América Economía in 2004, 2005 and 2006 respectively (see further $<$ http://www. americaeconomia.com/rankings $>$ ). Programmes at ITAM failed to make the Financial Times top 100 ranking between 2003 and 2006, but those at IPADE and EGADE (ITESM) were included (see further $<$ http://rankings.ft.com/businessschoolrankings $>$ ).

${ }^{73}$ On the contributions of ITAM's undergraduates in economics to the Mexican public service elites, see further Babb, Managing, 2001.

${ }_{74}$ Pilar Álvarez del Castillo, Fianzas Atlas; Elda Emilia Cota Miranda, Grupo Venta Internacional; Andrea Criszanar, Pensiones Banorte Generali; Iliana Gámez, Zimag Logistics, and Simona Viztova, Sam's Club. 
of entrepreneurial elites between 1970 and 2005. Another area in need of attention is the possibility of Americanisation before 1945, for there is evidence of rising direct investment by US companies from the end of the nineteenth century until 1924 .

The reason here educed why Mexicans adopted the Anglo-American educational model is somewhat different from those in previous studies. In particular, much has been said of the promise that the MBA would be a feeder course for future leaders of industry in the USA or Britain in contrast with the fact that it transformed higher education teachers into purveyors of a standard product (the MBA, whose structure and syllabus have remained intact since the late 1990s) and the students into consumers. ${ }^{75}$ Yet such grandiose expectations were never part of the Mexican narrative.

Consistent with their agricultural roots and European heritage, Mexicans had an "organic" conception of the firm, as opposed to the (American) "mechanistic" concept. ${ }^{76}$ Indeed, a recurrent criticism by early US researchers of Mexican nationalist entrepreneurs, is that the Mexican "upper crust" believed in bringing gains to themselves and their fellow citizens. ${ }^{77}$ In this context, the pursuit of higher education in Europe was not to acquire technical knowledge as much as a response, "broadening the mind", to the lack of opportunities at home. ${ }^{78}$ But the Mexican elites' educational goals and destination underwent a transformation when, spurred by a government-sponsored drive for industrialization at home, they joined a general educational movement towards Anglo-American capitalism (together, therefore, with their universities and university models). Americanisation resulted in a dramatic change in Mexico which impacted on all higher education institutions, including such corner-stones of the Revolution as the Army. ${ }^{79}$

${ }^{75}$ See among others Locke, End, 1984, Management, 1989, Collapse, 1996 and Management, 1998; Locke and Schöne, Entrepreneurial, 2004; Thomas, "British", 1978, and Controversies, 2003; Whitley, Thomas and Marceau, Masters, 1981, and more recently Khurana, From, 2007, and Williams, History, 2010.

${ }^{76}$ Locke, Collapse, 1996.

${ }_{77}^{77}$ Lauterbach, "Management”, 1965, and Womack, "Spoils", 1979.

${ }^{78}$ Personal interviews with Elena Pozzi Pardo, "De la UNAM a mi doctorado en Biología en Italia", December 15, 2005; with Miguel Escobedo, "Qué bien me la pasé en París", December 15, 2005, and with Julio Zamora Bátiz, "Mi doctorado en Economía en Austin, Texas", December 20, 2005, interviewed by Bernardo Bátiz-Lazo.

${ }^{79}$ From its foundation in the nineteenth century the Heroico Colegio Militar, the school for Army officers (which gained its prestigious name during the US-Mexican war), had emphasized French-style engineering studies. Engineering was the career path that young officers aspired to follow as a sure way to make a name for themselves. During the 1950s, however, engineers lost out "at a double step" to Diplomados del Estado Mayor, that is, graduates of West Point-style programmes. 
In a way, the creation of graduate and postgraduate courses in management at the UNAM amounted to catching up with programmes already on offer at independent private schools -where graduate and undergraduate business and management education had spread rapidly and successfully. At the same time, the efforts at IPN but primarily those at UNAM illustrate how state schools grow and change easily in response to social demands for education and at the same time how new programmes emerge from cosmetic changes, reorganisations and improvements of existing provision rather than outright innovations in education. ${ }^{80}$ Yet graduate education can be associated with a shift in family-run firms as greater numbers of salaried staff were incorporated, some even to executive positions. The country was also changing and becoming more urban and better educated.

An increase in the adoption of postgraduate management education by Mexicans links up with powerful "domestic" factors, namely, the pressure on Mexican companies to develop policies which would accelerate productivity growth and technical change as barriers to trade came down. This was more the case in the 1990s, because hardly any of the biggest firms at the end of the 1970s (as measured by Ceceña ${ }^{81}$ or Cerda ${ }^{82}$ ) survived the dual process of reform and trade liberalization in the 1980s. Taking up US methods of production and management became a top concern for local business and the entry of multinational companies (mainly through acquisition ${ }^{83}$ ) resulted in gaining an attractive opportunity directly from the source. But this was possible for elites, that is, those able and willing to overcome the economic cost of two years of full-time education abroad. It remains an open question whether these individuals reaching the top echelons of US multinational companies (whether abroad or in their Mexican subsidiaries) were directly or indirectly related to the families and groups controlling the biggest firms at the end of the 1970s.

${ }^{80}$ Meneses, Universidad, 1979, pp. 49-50.

${ }^{81}$ Ceceña, México, 1975.

${ }^{82}$ Cerda, Leading, 2007.

${ }^{83}$ Bátiz-Lazo, Blanco and Urionabarrenetxea, "Growth", 2007. 


\section{APPENDIX}

\section{The CASE METHOD IN MeXiCO}

There is widespread agreement that the teaching case method is as ever the centre of teaching and learning in an MBA. ${ }^{84}$ Its attractiveness has been that of introducing "real life" situations into the classroom. This method became synonymous with the MBA after it was honed at Harvard University (imported from the Law School into the Business School) in the 1920s, from where it spread widely, reaching Europe during the 1950s. The case method is one of the pedagogical tools or indeed institutions by which US-style management education is delivered. Hence, its use in Mexico or around Mexican companies is revealing.

According to Rossell, in Mexico in the early 1960s the case method was "unknown". ${ }^{85}$ The same source claims that at the time only two outlets offered regular training programmes for top executives in Mexico City: the independent American Management Association and the Institute of Scientific Business Administration (Instituto de Administración Científica de las Empresas) which had the support of the leading trade associations for business (Confederación Patronal de la República Mexicana, CopaRMEX). Neither of these, says Rossell, used teaching case studies.

The apparent dearth of indigenous expertise led to the myth that IPADE had introducing the case method as an innovation in Mexico and even Latin America. But there is substantial historical evidence to contest Rossell's claims. ${ }^{86}$ There were other groups working in relative isolation and looking to introduce US-style management education, who were either aware of or actually using teaching case studies. For instance, there is evidence of professors from US business schools (e. g. Russell L. Ackoff from the Wharton School at the University of Pennsylvania) visiting Mexico as early as August 1964 to teach top Mexican executives (e. g. Bernardo Quintana Arrioja and his group at Asociación de Ingenieros Civiles, ICA). ${ }^{87}$ Ackoff did not use the case method but "fables" in their training, suggesting that although the idea of introducing "real life" was known in the USA and Europe it was not necessarily embodied by the Harvard-style case study (that is, the reading of an already prepared draft followed by some form of debate). The case method approach was in the process of diffusing

\footnotetext{
${ }^{84}$ Ellet, Case, 2007; Llano, Enseñanza, 1996; Mintzberg, Managers, 2004, and Starkey and Tiratsoo, Business, 2007.

${ }^{85}$ Unless otherwise stated, this paragraph borrows freely from Rossell, Vivencias, 2007.

${ }^{86}$ A similar claim to that in Rossell Alvares' Vivencias is found in Llano, Enseñanza, 1996.

${ }^{87}$ Personal correspondence with Bernardo Bátiz-Echavarria, "Ackoff en México", December 9, 2008.
} 
itself. At ITESM in Monterrey it was incorporated in undergraduate programmes during the $1950 \mathrm{~s}$ and first used in postgraduate courses in $1964 .^{88}$ Therefore, given the relative isolation and the scattered nature of alternative efforts to introduce US-style education to Mexican graduate studies in business and management, while it is not altogether clear who was the first Mexican or training programme in Mexico to use the teaching case study, it was certainly well before 1967 (e. g. the date that IPADE was established).

Other signs of awareness of US-style education in Mexican graduate courses can be found at the Universidad Iberoamericana (run by Jesuits), where Isaac Guzmán Valdivia was actively writing on business and management ${ }^{89}$ Moreover, some of the staff had even achieved higher degrees in the area by research, for instance, José Antonio Fernández Arenas. He was a graduate of the dual accounting and management programme from UNAM in 1964, received a doctorate in management from Northwestern University, taught at Kansas and Stanford in the USA and became external advisor to the School of Management and Industrial Relations (Escuela de Administración y Relaciones Industriales) at UIA, as well as the head of the ENCA at UNAM. ${ }^{90}$

But people with the background of Fernández Arenas were extremely scarce. Instead, local expertise largely developed through teacher training courses. These aimed to help academic staff familiarise themselves with some of the content of US-style management education. This was key for courses in "planning" and "organization", for which there was no firmly established theoretical framework and this was where the use of teaching case studies sought to develop students' analytical skills. ${ }^{91}$ Starting in 1956, the Mexican Institute of Business Management (Instituto Mexicano de Administración de Negocios, here forth IMAN) offered executive training courses using US-style teaching case studies. ${ }^{92}$ In 1959, Donald B. Campbell, director of IMAN, teamed up with the ENCA to offer a 20 week (two hours per week) teacher training course, to 20 participants, who would also develop teaching cases based on Mexican enterprises. ${ }^{93}$

Contextualising US management programmes and content was a common aspiration of the Mexicans involved in management education. Moreover, it was often cited as part of the school's and teachers' duties and

\footnotetext{
${ }^{88}$ Personal correspondence with Germán Otalora Bay, "El método de caso en el ITESM", November 11, 2008.

${ }^{89}$ These included Guzmán, Reflexiones, 1961, and Sociología, 1963.

${ }^{90}$ Wadia and Fernández, "Administración”, 1964.

${ }^{91}$ Mancera, "Seminario", 1959, and Marchini, "Primera”, 1958.

${ }^{92}$ Arreola, "Método", 1959.

${ }^{93}$ Mancera, "Seminario", 1959.
} 
responsibilities. ${ }^{94}$ This is understandable from the need to adapt students to their labour market, when most international exchanges took place through arms-length trading, the nationalist sentiment that characterised Mexico in the aftermath of the Revolution and frequent calls for Latin American integration. ${ }^{95}$

No record has been found regarding IMAN after 1960, while none of the interviewees had any recollection of IMAN nor of any indigenous case clearing house. However, IMAN was listed as one of the contributors to the bibliography of teaching material in business and management in Latin America compiled by Towl and Hetherson. ${ }^{96}$ The appeal for cases to list asked for both cases originating in one country and the teaching material used there and although the material was not translated, it was requested that information about the case should be given only in English. ${ }^{97}$ As a result, in 1966, an initial contribution of teaching material was deposited at what was then called the Intercollegiate Case Clearing House (ICCH), comprising 603 cases specified for Latin America, of which 76 had a setting in Mexico or dealt with Mexican companies. Of these, 60 entries had been contributed by IMAN (eight in English and 52 in Spanish).

The aim in setting up an international collection at the ICCH was to have for original listings of cases augmented by subsequent indigenous production, as well as the productions of international scholars. Table 1 summarises an examination of the archival records comprising teaching case studies with a setting in Mexico or focusing on Mexican companies. This has been available since 1966 through the Intercollegiate Case Clearing House (in 1981 renamed the Harvard Business School Case Services) and since 1973 through the Case Clearing House of Britain and Ireland (which amalgamated other European collections and in 1991 was renamed the European Case Clearing House, ECCH).

Table 1 shows that archival research identified 254 teaching cases with a setting in Mexico or focusing on a Mexican company. These teaching cases were first printed between 1947 and 2005. Two titles had an historical

${ }^{94}$ Anonymous, "Encuesta", 1959, p. 58, "Escuela", 1965, p. 61, "Estudios", 1965, p. 37, and "Facultad", 1979, p. 67; Fernández, "Historia”, 1964, p. 64; Mancera, "Seminario", 1959, p. 35; Pallares, "Cómo", 1956, p. 7, and "Nuevo", 1957, p. 93, and Sisto, "Administración", 1960, p. 11.

${ }^{95}$ The chief aim was to transform and accelerate the development of Latin American countries through gradual and pacific reform. However, the lack of interest among entrepreneurial elites resulted in the failure of such initiatives (including those dealing with technology transfer). See Flores, Dentro, 1973, p. 221.

${ }_{96}$ Towl and Hetherson, Case, 1966, p. 276.

${ }^{97}$ Linfords, Gebhard and Towl, Case, 1969, p. XIII. 


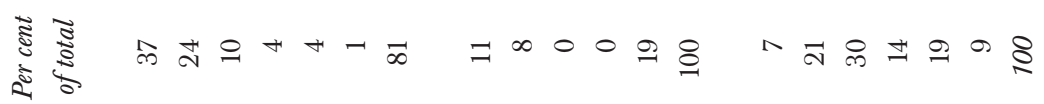

音

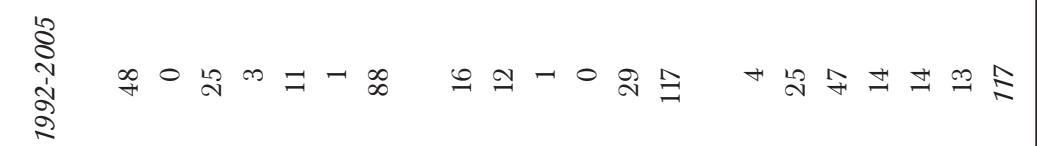

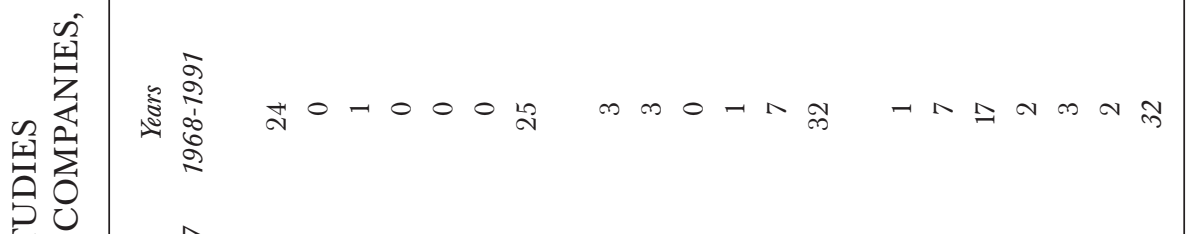

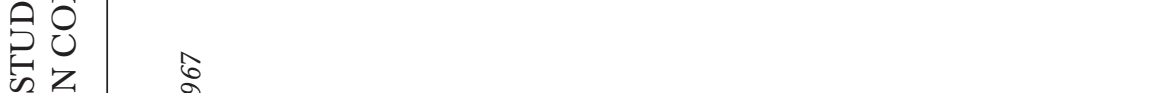

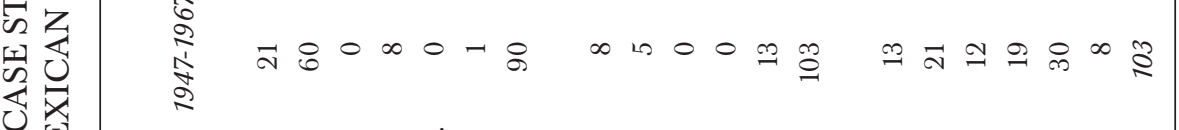

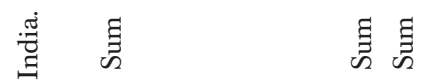

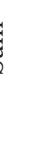

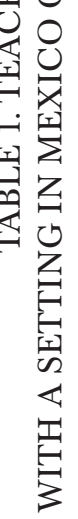

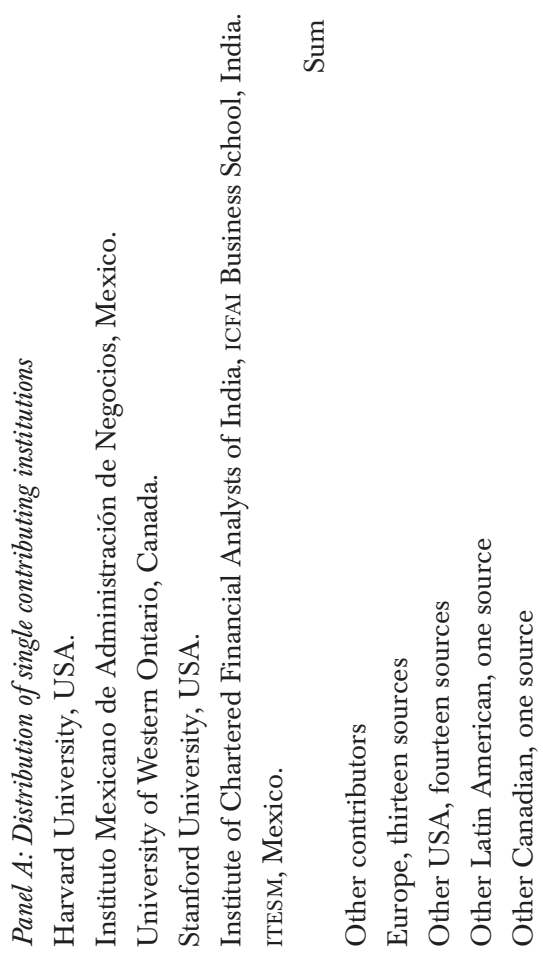


setting and were excluded from further analysis. ${ }^{98}$ Most entries were printed within two years of their setting (229 entries, 91\%), while all but one of the revisions took place were made to teaching cases first printed before 1992. Of the 252 entries, 103, 41\%, were set before 196, 32 teaching cases, 13\%, between 1968 and 1991, and 117 cases, 46\%, between 1992 and 2005 .

The distribution of teaching cases shows the very important contribution of indigenous authors (chiefly from IMAN) in the early years and the pre-eminence of Harvard-based authors in recent years. Indeed, there were 53 teaching cases in Spanish (51 from IMAN and one from Stanford) and thus, 200 entries, 79\%, in English. Over half of these English-only teaching cases (102 entries) were first printed between 1995 and 2005. The main source of material was field studies (136 entries, 41\%) while 44 cases, $17 \%$, used published sources and 69 entries failed to specify, 27 per cent.

Yet IMAN'S 60 entries, 24\%, and ITESM two entries, $1 \%$, were the only two sources of contributions by indigenous authors to the clearing-house database. There is a dearth of contributions by other leading graduate outlets, such as IPADE and ITAM. Still, authors from 32 universities have written case studies with a setting in Mexico or looking at Mexican companies. The main contributing institution was Harvard University, with 93 entries, 37\%; followed by the Richard Ivey School of Business, Western Ontario, with 26 entries, 10\%; Stanford University and the ICFAI Business School, each contributed eleven teaching cases, $4 \%$ each. Authors based in 29 other European and US universities contributed 49 teaching cases altogether, 19 per cent.

If the teaching case study is germane to the modern conception of the MBA, contributions from European and Asian (e. g. ICFAI) authors are particularly important. They suggest there are interesting developments in Mexico and the Mexican enterprise which illustrate developments in global business. Yet the scarcity of indigenous contributions compared with the overwhelming US production would suggest that Mexican teachers and administrators of local MBA programmes are happy to accept a US-based view of the business world.

Further examination of the database suggests that the large and diverse distribution of authors had produced teaching case studies which primarily dealt with multinational companies in Mexico rather than focusing on Mexican companies (see table 2) ${ }^{99} 103$ entries, $41 \%$, dealt with a multina-

${ }^{98}$ These were "The Case of Miguel Hidalgo y Costilla (1753-1811) and of José María Morelos y Pavón [sic] (1765-1815)" by S. M. Garrett, ref. 9475 655, and "Weetman Pearson and the Mexican Oil Industry" by G. Jones and L. Bud-Freirman, L, ref. 9804085.

${ }_{99}$ Although the teaching case method is primarily a pedagogical tool, others have used it to explore corporate strategy. For instance Whittington, Mayer and Curto, "Chandlerism", 1999, p. 531. 


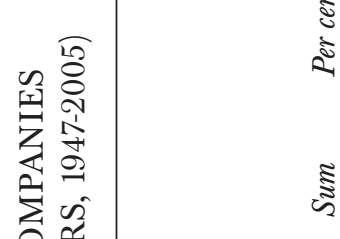

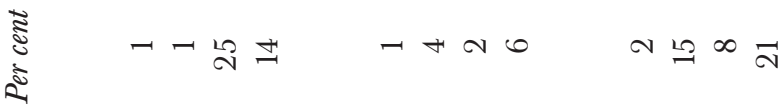

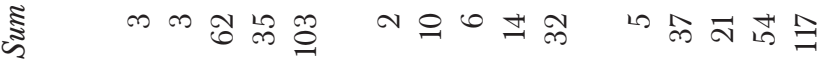

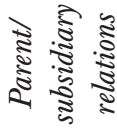

$\rightarrow O H=0$ N

$\mathrm{i}$
$\mathrm{i}$

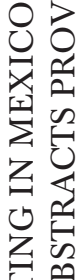

是

牙

$\varangle$

田

$3 \sum_{0}^{\infty}$

되 온

될

ひ焉

政

当艺

导艺

포

เั่

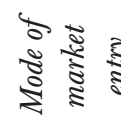

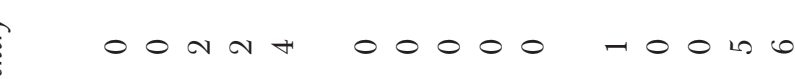

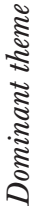

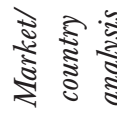

On-O

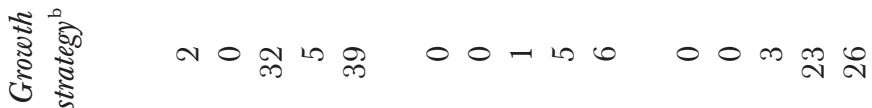

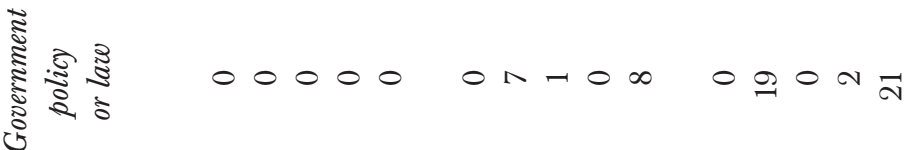

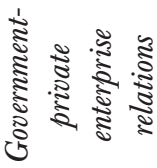

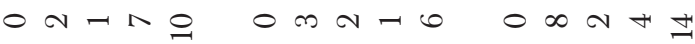

只是

䒠

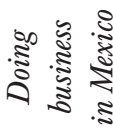

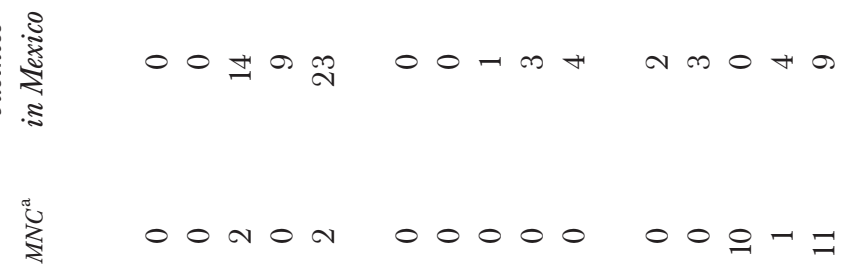

党是

究厌

ชิ

舵

ㄱ Z

됨

突彭

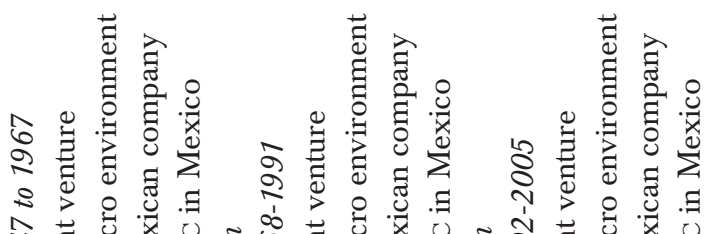

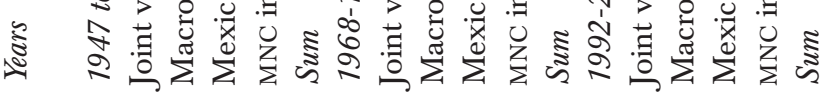




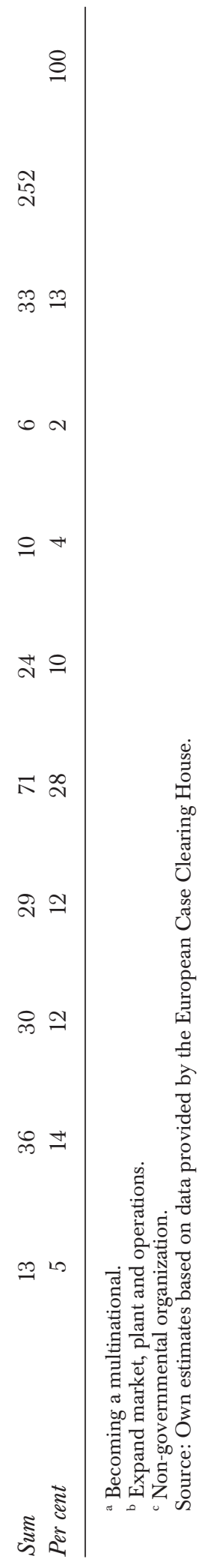


tional company in Mexico, 89 entries, 35\%, with Mexican companies and ten entries, $4 \%$, with joint ventures. Teaching cases dealing with Mexican companies were contributed mainly in the opening years by authors based at IMAN; there were 62 entries between 1947 and 1966, but only six entries between 1968 and 1991, and 21 entries between 1992 and 2005.

50 entries, 20\%, dealt with the macro environment, which reflected the preoccupation of international authors to understand the policies of the Mexican government. Table 2 also shows that 71 entries dealt with market growth, $28 \%$. This made it the most popular theme within the teaching case studies. There was no other main dominant theme although most could be categorised as part of an "international business" course syllabus.

\section{BIBLIOGRAPHY}

Ackoff, Russell L., Some Observations and Reflectios on Mexican Development, Philadelphia, University of Pennsylvania, 1976.

Álvarez Mendiola, Germán, Educación superior, Mexico, Secretaría de Educación Pública/Organización de Estados Iberoamericanos para la Educación, la Ciencia y la Cultura, 1994.

Ángel MobaraK, Gustavo Del, The Corporate Governance of the Mexican Banking System. A Historical Perspective: 1940-2000, Mexico, Centro de Investigación y Docencia Económicas, 2002 (Working Papers, issue 373), in <http://www.cide.edu/publicaciones/status/dts/DTE\%20373.pdf>.

BBVA BANCOMER: 75 años de historia, Mexico, Grupo Financiero BBVA BANCOMER, 2007.

ANONYMous, "Una encuesta sobre la carrera de licenciado en Administración de Empresas", Contabilidad-Administración, vol. 10, March, 1959, pp. 57-60.

, "Escuela de Contabilidad, Economía y Administración (Instituto Tecnológico y de Estudios Superiores de Monterrey)", Contabilidad-Administración, vol. 34: Memoria de la Quinta Conferencia de Facultades y Escuelas de Administración de la República Mexicana (second part), March, 1965, pp. 59-63.

, "Estudios superiores", Contabilidad-Administración, vol. 35: Memoria de la Quinta Conferencia de Facultades y Escuelas de Administración de la República Mexicana (third part), June, 1965.

, "Facultad de Contaduría y Administración" in Gulllermo Soberón (ed.), Festejos conmemorativos del 50 aniversario de la UNAM, Mexico, Universidad Nacional Autónoma de México, 1979, pp. 67-95.

Arreola Loperena, Jorge, "El 'método de caso' en la enseñanza de la administración de empresas”, Contabilidad-Administración, vol. 10, March, 1959, pp. 51-55. 
Arriola, CARlos, “Los grupos empresariales frente al Estado, 1973-1975”, Foro Internacional, El Colegio de México, vol. 16, issue 4 (64), April-June, 1976, Mexico, pp. 449-495.

Arzuaga Magnoni, Javier, Racionalidad empresarial. Los megaempresarios mexicanos, Mexico, Gernika, 2004.

Aspe Armella, María Luisa, "Un caso de integralismo interruptus 1929-1958: la supuesta homogeneidad de la Acción Católica y su contradicción interna en relación a la política”, doctoral dissertation in History, Mexico, Universidad Iberoamericana, 2004.

Aubrey, Robert, "Capital Mobilization and the Patterns of Business Ownership and Control in Latin America: the Case of Mexico" in Sidney Greenfield (ed.), Entrepreneurship in Cultural Context, Albuquerque, University of New Mexico Press, 1979.

Aveleyra Arroyo de Anda, Pablo, Notas sobre el Departamento de Estudios Económicos del Banco Nacional de México, Mexico, BanameX, 1988.

BABb, SARAH L., Managing Mexico: Economics from Nationalism to Neoliberalism, Oxford, Princeton University Press, 2001.

Bátiz-Lazo, Bernardo, Ana Blanco Mendialdua and Sara Urionabarrenetxea ZabalandikoetXeA, "Growth of the Spanish Multinational in Latin America during the 1990s", Latin American Business Review, vol. 8, issue 1, 2007, pp. 1-36.

Bátiz-Lazo, Bernardo and Thomas Haigh, "Engineering Change: The Appropriation of Computer Technology at Grupo ICA in Mexico (1965-1971)", IEEE Annals in the History of Computing, Institute of Electrical and Electronics Engineers, vol. 34, April-June, 2012, pp. 2-15.

Baughman, James P., "Recent Trends in the Business History of Latin America", Business History Review, The President and Fellows of Harvard College, vol. 39, issue 4, winter, 1965, Massachusetts, pp. 425-438.

Bensabet Kleinberg, Remonda, "Strategic Alliances: State-Business Relations in Mexico under Neoliberalism and Crisis", Bulletin of Latin American Research, Society for Latin American Studies, vol. 18, issue 1, 1999, pp. 71-78.

CAmp, Roderic, Entrepreneur and Politics in Twentieth-Century Mexico, Oxford, Oxford University Press, 1989.

Carrera Montesinos, Rafael, "Empresarios en el nuevo orden estatal”, El Cotidiano, Universidad Autónoma de México, vol. 8, issue 50, September-October, 1992, Mexico, pp. 108-114.

Ceceña, José Luis, México en la órbita imperial, Mexico, El Caballito, 1975.

Cerda, José DE LA, "The Leading Business Companies of Mexico 1975-2005: Survivors and out Performers of the Global Economic Revolution", doctoral dissertation in Business, Chicago, Benedictine University, 2007.

Cerón Anaya, Hugo, "Identity of the Mexican Entrepreneurial Elite, 1970-1980", master's degree dissertation in Sociology, Colchester, University of Essex, 2003. 
Cerutti, Mario and Carlos Marichal, Grandes empresas y grupos empresariales en México, Mexico, Plaza y Valdés, 2010.

Chandler, Alfred Jr., Scale and Scope: The Dynamics of Industrial Capitalism, Cambridge, Harvard University Press, 1990.

Contreras, Joseph, Tan lejos de Dios: el México moderno a la sombra de Estados Unidos, Mexico, Grijalbo, 2006.

Ellet, William, The Case Study Handbook, Boston, Harvard Business School Press, 2007.

Fernández Arena, José Antonio, "Historia de la Administración (primera parte)", Contabilidad-Administración, vol. 33, December, 1964.

Flores, Edmundo, Dentro y fuera del desarrollo, Mexico, Fondo de Cultura Económica, 1973.

GarcíA-Verdú, Rodrigo, "Demographics, Human Capital and Economic Growth in Mexico: 1950-2005", conference on Growth in Latin America Economic Development Division, Santiago (Chile), United Nation's Economic Commission for Latin America and the Caribbean, 2007.

Garrido, Celso, "El liderazgo de las grandes empresas industriales mexicanas" in Wilson Peres y Celso Garrido (eds.), Grandes empresas y grupos industriales latinoamericanos, Mexico, Siglo XXI/Comisión Económica para América Latina, 1998, pp. 397-470.

GuZMÁn VALDIVIA, IsAac, Reflexiones sobre la administración, Mexico, Reverte, 1961. La sociología de la empresa, Mexico, Jus, 1963.

Hernández Rodríguez, Rogelio, "La conducta empresarial en el gobierno de Miguel de la Madrid”, Foro Internacional, El Colegio de México, vol. 30, issue 4 (120), April-June, 1990, Mexico, pp. 736-764.

, Empresarios, banca y Estado: el conflicto durante el gobierno de López Portillo, 1976-1982, Mexico, Miguel Ángel Porrúa, 1991.

Hoshino, TAEKo, "Indigenous Corporate Groups in Mexico: High Growth and Qualitative Change in the 1970s and the Early 1980s", The Developing Economies, Institute of Developing Economies, vol. 28, issue 3, September, 1990, pp. 302-328.

"Family Business in Mexico: Responses to Human Resource Limitations and Management Succession", Japan, Institute of Developing Economies, 2004 (Discussion papers, issue 12).

"Executive Managers in Large Mexican Family Businesses", Japan, Institute of Developing Economies, 2005 (Discussion papers, issue 40).

Huerta Nava, RaQuel, Agustín Legorreta García. Líder empresarial, Mexico, Vila Editores, 2005.

Instituto Nacional PARA la Evaluación de la EdUCACIÓn, Anuario panorama educativo de México: indicadores del sistema educativo nacional, Mexico, Instituto Nacional para la Evaluación de la Educación, 2004. 
Khurana, RaKesh, From Higher Aims to Higher Hands: The Social Transformation of American Business Schools and the Unfulfilled Promise of Management as a Profession, Princeton and Oxford, Princeton University Press, 2007.

Kipping, Matthias, Behlül Üsdiken and Núria Puig, "Imitation, Tension and Hybridization: Multiple 'Americanizations' of Management Education in Mediterranean Europe", Journal of Management Inquiry, Western Academy of Management, vol. 13, issue 2, June, 2004, pp. 98-108.

Kuing, Merle, A Mexican Interest Group in Action, Englewood, Prentice-Hall, 1961.

Lauterbach, Albert, "Executive Training and Productivity: Managerial Views in Latin America”, Industrial and Labor Relations Review, Cornell University, vol. 17, issue 3, 1964, pp. 357-379.

"Management Aims and Development Needs in Latin America", Business History Review, The President and Fellows of Harvard College, vol. 39, issue 4, winter, 1965, pp. 557-588.

Linfords, Grace V., Charles N. Gebhard and Andrew R. Towl, Case and Other Materials for the Teaching of Business Administration in Developing Countries: Comparative Index, Boston, Harvard University, 1969.

Llano Cifuentes, Carlos, La enseñanza de la dirección y el método de caso, Mexico, Universidad Panamericana, 1996.

LOCKe, Robert R., The End of the Practical Man: Entrepreneurship and Higher Education in Germany, France, and Great Britain, 1880-1940, Greenwich, JAI Press, 1984.

, Management and Higher Education since 1940: The Influence of America and Japan on West Germany, Great Britain, and France, Cambridge and New York, Cambridge University Press, 1989.

The Collapse of the American Management Mystique, Oxford and New York, Oxford University Press, 1996.

Management Education, Ashgate, Aldershot, 1998. and Katja E. SCHÖNE, The Entrepreneurial Shift: Americanization in European

High-Technology Management Education, Cambridge, Cambridge University Press, 2004.

Lumsden, IAn, The Americanization of Canada, Toronto \& Buffalo, University of Toronto Press, 1970.

Luna, Matilde, "Business and Politics in Mexico" in Kevin Middlebrook (ed.), Dilemmas of Political Change in Mexico, London, University of London/University of California, 2004, pp. 332-352.

Madrid Hurtado, Miguel de la, Cambio de rumbo. Testimonio de una presidencia, 19821988, Mexico, Fondo de Cultura Económica, 2004.

Mancera Aguayo, Gabriel, "Seminario sobre el "método de caso", ContabilidadAdministración, vol. 11, June, 1959, pp. 33-35.

MARCHINI, ISA, "La primera sesión de perfeccionamiento para docentes europeos de administración de empresas", Contabilidad-Administración, vol. 8, September, 1958, pp. 3-14. 
Marichal, Carlos and Mario Cerutti, Historia de las grandes empresas en México, 1850-1930, Mexico, Fondo de Cultura Económica, 1997.

Martínez, Zaida L. and David A. Ricks, “Multinational Parent Companies' Influence over Human Resource Decisions of Affiliates: U.S. Firms in Mexico", Journal of International Business Studies, Academy of International Business, vol. 20, issue 3, September, 1989, pp. 465-487.

MaXfield, SylviA, Governing Capital: International Finance and Mexican Politics, Ithaca, Cornell University Press, 1990.

and Ricardo AnZaldúa, Government and Private Sector in Contemporary Mexico, California, Centre for US-Mexican Studies, 1987.

McGlade, JacQueline, "From Business Reform to Production Drive: The Transformation of US Technical Assistance to Western Europe" in MatThias KIPPING and Ove BJARnAR (eds.), The Americanisation of European Business: The Marshall Plan and the Transfer of US Management Models, London, Routledge, 1998, pp. 18-34.

Meneses, ERnesto, La Universidad Iberoamericana en el contexto de la educación superior contemporánea, Mexico, Universidad Iberoamericana, 1979.

Mintzberg, Henry, Managers not MBAs, London, Pearson Education, 2004.

MizRahi, Yemile, The New Conservative Opposition: The Politics of Entrepreneurs in Chihuahua, Berkeley,University of California, 1994.

Montaño Hirose, Luis, "La investigación en administración. Reflexiones para el caso de México", Administración y Organizaciones, Universidad Autónoma Metropolitana, vol. 1, issue 2, July, 1999, Mexico, pp. 7-20.

Negrón de Montilla, Aida, La americanización de Puerto Rico y el sistema de instrucción pública (1900-1930), Rio Piedras, Universidad de Puerto Rico, 1976.

Olvera Zapata, Miguel, Diálogos con don Alejandro Prieto. Padre del sincretismo contable moderno, Mexico, Instituto Mexicano de Contadores Públicos, 2005.

Ortiz Martínez, Guillermo, "70 Aniversario de la Escuela Bancaria y Comercial”, 1999, retrieved December 31, 2004, from <http://www.banxico.org.mx/gPublicaciones/Discursos/gom-ebc.html $>$.

Ortiz Rivera, Alicia, "El Consejo Mexicano de Hombres de Negocios: órgano de acción política de la elite empresarial”, Revista Mexicana de Sociología, Universidad Nacional Autónoma de México, vol. 64, issue 1, 2002, Mexico, pp. 101-139.

Pallares, Eduardo, “Cómo es la Escuela Nacional de Comercio y Administración”, Contabilidad-Administración, vol. 1, October, 1956, pp. 3-13.

"Nuevo director en nuestra escuela", Contabilidad-Administración, vol. 4, September, 1957, pp. 93-98.

Pariente Fragoso, José Luis, "La formación de administradores en el nuevo entorno internacional”, Contabilidad-Administración, vol. 220, September, 2006, pp. 123-144.

Preston, Julia and Samuel Dillon, El despertar de México, Mexico, Océano de México, 2004. 
Puga, CRistina, Organizaciones empresariales y el Tratado de Libre Comercio, Mexico, Universidad Nacional Autónoma de México, 1993.

Puig, Nuria and Paloma Fernández, "The Education of Spanish Entrepreneurs and Managers: Madrid and Barcelona Business Schools, 1950-1975”, Paedagogica Historica, Carfax Publishing Limited, vol. 39, issue 5, 2003, pp. 651-672.

Purcell, John and Susan Kaufman Purcell, "Mexican Business and Public Policy" in James Malloy (ed.), Authoritarianism and Corporatism in Latin America, Pittsburgh, University of Pittsburgh Press, 1977.

Recio, Gabriela, "Lawyers' Contribution to Business Development in Early Twentieth-Century Mexico", Enterprise and Society, The Business History Conference, vol. 5, issue 2, pp. 281-306, 2004, pp. 281-306.

Rodríguez Álvarez, María de los Ángeles, Escuela Superior de Comercio y Administración 1845-1995, Mexico, Instituto Politécnico Nacional, 1995.

Romero Ibarra, María Eugenia, "Panorama general del desarrollo de la historia empresarial en México", Historia Mexicana, El Colegio de México, vol. 52, issue 3, 2003, Mexico, pp. 831-872.

Rossell Álvarez, Carlos, Vivencias de 40 años en el IPADE, Mexico, Universidad Panamericana, 2007.

Rossi, Flavia De, El empresario mexicano, Mexico, Universidad Nacional Autónoma de México, 1977.

Salas Porras, Alejandra, "Avenidas de desarrollo de los grandes grupos empresariales mexicanos”, Revista Mexicana de Sociología, Universidad Nacional Autónoma de México, vol. 64, issue 1, 2002, Mexico, pp. 141-185.

Schneider, Ben Ross, "Why is Mexican Business so Organized?", Latin American Research Review, Latin American Studies Association, vol. 37, issue 1, 2002, pp. 77-118.

Schuler, Randall S. et al., "Managing Human Resources in Mexico: A Cultural Understanding”, Business Horizons, Indiana University, vol. 39, issue 3, May-June, 1996, pp. 55-61.

Shafer, Robert, Mexican Business Organisations. History and Analysis, Syracuse, Syracuse University Press, 1973.

Silva, Luz María, "Banco Nacional de México: 115 años de BANAmeX”, unpublished, Mexico, Archivo Banamex, 1999.

Sisto Velasco, Eugenio, "La administración, base fundamental en el desarrollo de la empresa”, Contabilidad-Administración, vol. 15, March, 1960, pp. 5-11.

Slocum JR., John W., "A Comparative Study of the Satisfaction of American and Mexican Operatives", Academy of Management Journal, Academy of Management, vol. 14, issue 1, 1971, pp. 89-97.

Starkey, Ken and Nick Tiratsoo, The Business School and the Bottom Line, Cambridge, Cambridge University Press, 2007. 
Story, DAle, "Industrial Elite in Mexico: Political Ideology and Influence", Journal of Interamerican Studies and World Affairs, University of Miami, vol. 25, issue 3, August, 1983, pp. 351-376.

Thomas, Alan B., "The British Business Elite: The Case of the Retail Sector", Sociological Review, vol. 26, issue 2, Februabry, 1978, pp. 305-326.

Controversies in Management: Issues, Debates and Answers, London and New York, Routledge, 2nd. ed., 2003.

Towl, Andrew R. and Ruth C. Hetherson, Case and Other Materials for the Teaching of Business Administration in Developing Countries: Latin America, Boston, Harvard University, 1966.

Tucker, William P., "Mexican Elites", The Journal of Politics, Southern Political Science Association, vol. 31, issue 3, August, 1969, pp. 804-807.

Valdés Ugalde, Francisco, "From Bank Nationalization to State Reform: Business and the New Mexican Order" in Lorena Maria Cook, Kevin Middlebrook and Juan Molinar Horcasitas (eds.), The Politics of Economic Restructuring: State-Society Relations and Regime Change in Mexico, La Jolla, Center for US-Mexican Studies-University of California, 1994, pp. 219-242.

Vernon, Raymond, Public Policy and Private Enterprise in Mexico, Cambridge, Cambridge University Press, 1964.

Wadia, Maneck S. and José Antonio Fernández Arena, "La administración como ciencia (primera parte)", Contabilidad-Administración, vol. 30, March, 1964, pp. 40-61.

Whitley, Richard, Alan B. Thomas and Jane Marceau, Masters of Business? Business Schools and Business Graduates in Britain and France, London, Tavistock Publications Ltd., 1981.

Whittington, Richard, Michael Mayer and Francesco Curto, "Chandlerism in Post-war Europe: Strategic and Structural Change in France, Germany and the UK, 1950-1993", Industrial and Corporate Change, Oxford University Press, vol. 8, issue 3, September, 1999, pp. 519-551.

Wilkie, James W., Enrique C. OchoA and David E. Lorey, Statistical Abstract of Latin America, Los Angeles, University of California, 1993, vol. 30.

Williams, Allan P. O., The History of UK Business and Management Education, Bingley, Emerald Group/Association of Business Schools, 2010.

Wionczek, Miguel S., "The State and the Electric-Power Industry in Mexico, 18951965", Business History Review, The President and Fellows of Harvard College, vol. 39, issue 4: Special Latin American Issue, winter, 1965, pp. 527-556.

Womack JR., John, “The Spoils of the Mexican Revolution”, Foreign Affairs, Council on Foreign Relations, vol. 48, issue 4, July, 1979, pp. 677-687.

Zabludovsky, Gina, "Presencia de las empresarias en México: diagnóstico comparativo regional y mundial", Revista Mexicana de Sociología, Universidad Nacional Autónoma de México, vol. 57, issue 4, 1995, Mexico, pp. 255-285. 